EM

\title{
PROTAGONISMO DA REFORMA AGRÁRIA NO PARANÁ EM ÉPOCA DE PANDEMIA: AS AÇÕES DE SOLIDARIEDADE DO MST EM FATOS E FOTOS ${ }^{1}$
}

\author{
PROTAGONISMO DE LA REFORMA AGRARIA EN EL ESTADO DEL PARANÁ \\ (BRASIL), EN TIEMPOS DE PANDEMIA: LA SOLIDARIDAD POPULAR DEL MST EN \\ ACCIONES E IMÁGENES
}

\author{
Djoni ROOS* \\ Eliane Tomiasi PAULINO* \\ Gustavo SOARES* \\ Jorge MONTENEGRO*
}

\begin{abstract}
Resumo: A campanha permanente de criminalização da luta pela terra e de invisibilização das transformações promovidas pela justiça fundiária induz amplos setores da sociedade a condenarem a reforma agrária e os sujeitos que, por meio da luta, têm conseguido fazer valer os princípios constitucionais que a legitimam. Diante de tamanho desatino, a proposta deste texto é explicitar aquilo que dá certo quando tudo parece ruir. Nesses tempos em que a pandemia amplia a profunda crise econômica, sanitária e ética instalada no Brasil, propomos apresentar e refletir sobre a iniciativa do Movimento dos Trabalhadores Rurais Sem Terra (MST) de arrecadar alimentos produzidos pelas camponesas e camponeses de 54 acampamentos, 123 assentamentos, 21 comunidades de faxinalenses, posseiros, unidades de produção da agricultura familiar, escolas de agroecologia, cooperativas e sindicatos de trabalhadores rurais de 81 municípios distribuídos em todas as regiões do estado para doar a quem tem fome nas cidades. O mapa da solidariedade efetiva, traduzida em quase meio milhão de quilos de comida doados em 155 dias desde o início da ação, é fruto do cumprimento da função social da terra. Esse princípio a reveste do sentido civilizatório do cuidado com a casa comum. Em tempos em que os produtores de commodities lutam pela ampliação da permissividade aos agrotóxicos, pelo direito de incendiar para invadir terras protegidas e territórios ancestrais, explicitar esse jeito de plantar, colher e doar nos marcos da resistência, do trabalho árduo e da solidariedade é uma forma de assinalar que a ciência não pode ser neutra.
\end{abstract}

Palavras-Chave: Doação de alimentos; pandemia; reforma agrária; função social da terra.

Resumen: La campaña permanente de criminalización de la lucha por la tierra y de invisibilización de las transformaciones que promueve la tierra repartida induce a que amplios sectores de la sociedad condenen la reforma agraria y los sujetos que, por medio de la lucha, han conseguido poner en práctica los principios constitucionales que la legitiman. Contra este despropósito, la intención de este texto es mostrar lo que va bien cuando todo parece desmoronarse. En estos tiempos en que la pandemia amplía la profunda crisis económica, sanitaria y ética instalada en Brasil, proponemos exponer y reflexionar acerca de la iniciativa del Movimiento de Trabajadores Rurales Sin Tierra (MST) de reunir alimentos producidos por las campesinas y campesinos de 54 acampamentos, 123 assentamentos, 21 comunidades de faxinalenses, posseiros, unidades de producción de la agricultura familiar, escuelas de agroecología, cooperativas y sindicatos de trabajadores rurales de 81 municipios distribuidos entre todas las regiones paranaenses, para donar a quien tiene hambre en la ciudad. El mapa de una solidaridad que se consolidó en casi medio millón de kilos de comida donados en 155 días desde el principio de las acciones es fruto de la realización de la función social de la tierra. Este principio concede a la tierra el sentido civilizatorio del cuidado con la casa común. En momentos en que los productores de commodities luchan para que se amplíe el número de agrotóxicos y el derecho a incendiar para invadir tierras protegidas y territorios ancestrales, es necesario destacar esa forma de plantar, cosechar y donar en los marcos de la resistencia, del trabajo duro y de la solidaridad y reafirmar que la ciencia no puede ser neutra.

\footnotetext{
${ }^{1}$ Pesquisa realizada com apoio do CNPq, Processo 421027/2016-9.

* Membros do Observatório da Questão Agrária no Paraná (http://questaoagrariapr.blogspot.com/).
} 
EM

Palabras clave: Donación de alimentos; pandemia; reforma agraria; función social de la tierra.

\section{Introdução ${ }^{2}$}

Crises não admitem desdém, assim como pedem atitude e ações concretas. Mais ainda quando tomam vulto no país projetos de sociedade que relativizam os pilares do Estado de Direito e perturbam o sentido de valores fundamentais da humanidade como a vida, a liberdade e a solidariedade.

A propagação do novo Coronavírus (Sars-Cov2) e a doença que provoca, a Covid-19, tem espalhado luto pelas vidas perdidas ${ }^{3}$, porém tem sido mais devastadora dentre os mais pobres e os milhões de desempregados que já não tinham esperança quando a pandemia chegou. Outros tantos milhões acabaram esmagados em meio ao descontrole criminoso na gestão política, econômica e sanitária da crise. Frente a essa desrazão, iniciativas solidárias espalhadas por todo o país têm impedido que muitos sucumbam, a exemplo da mobilização realizada pelo Movimento dos Trabalhadores Rurais Sem Terra (MST) para arrecadação de alimentos dentre camponeses e camponesas assentados(as) e acampados(as) para doação a famílias que enfrentam a falta de renda, de trabalho e de reconhecimento de seus direitos básicos, cuja fila não para de crescer no país afora.

Embora essa seja uma iniciativa em escala nacional, nesse texto nos deteremos no caso do Paraná ${ }^{4}$, valendo-nos dos dados referentes às doações contabilizados pelo MST, de fotografias feitas por comunicadores e comunicadoras populares do movimento durante as ações de solidariedade e da convicção de fundo de que toda essa situação só vem reforçar a necessidade de entender que a questão agrária no Paraná segue aberta e o modelo de produção e distribuição do agronegócio só tem piorado o horizonte da distribuição dos alimentos, dos bens naturais e do emprego no campo.

Saliente-se que o espectro da solidariedade em tempos tão dramáticos é por demais diverso. Além das ações diretas aqui evidenciadas, existem outras organizadas coletivamente que contam com a presença do MST e de outros movimentos sociais e organizações do campo, movimento estudantil e sindicatos de professores, a exemplo dos comitês de resistência e solidariedade constituídos no Oeste e sudoeste do estado ${ }^{5}$ e das iniciativas como a da Grande Curitiba que podem ser consultadas na Plataforma Paraná contra a COVID-19 .

O percurso proposto neste texto passa por retratar a distribuição espacial dessa solidariedade no conjunto do estado do Paraná segundo grupos de mesorregiões ${ }^{7}$, tendo como recorte temporal o período de dois de abril, momento em que a primeira ação foi levada a cabo pela COPAVI (Cooperativa de Produção Agropecuária Vitória) no município de Paranacity, no Noroeste do estado, até o dia quatro de setembro, quando aconteceram as duas últimas ações segundo o imperativo de cessar a escrita, o que não significa fim da iniciativa. Essas envolveram os acampamentos Valdair Roque e Terra Livre, nos municípios de Quinta do Sol (mesorregião Centro Ocidental Paranaense) e de Clevelândia (mesorregião Centro-Sul

\footnotetext{
${ }^{2}$ Gostaríamos de agradecer a todas e todos que participaram das ações por seu exemplo e particularmente a Ednubia Ghisi do Setor de Comunicação e Cultura do MST/PR que nos fez o convite para escrever este artigo e nos forneceu informações fundamentais para compreender a magnitude e a mobilização que significam as ações de solidariedade. Foram imprescindíveis também as notícias publicadas no jornal Brasil de Fato-Paraná e na página do MST- Nacional para consultar sobre as ações concretas.

${ }^{3}$ Segundo a Fiocruz (2020), até 25 de setembro de 2020 o Brasil contabilizava 4.6694 .702 casos e 140.760 óbitos.

${ }^{4}$ No Paraná, até a mesma data (25/09) os casos somam 171.932 e 4.318 óbitos (FIOCRUZ, 2020).

${ }^{5} \mathrm{https}: / / \mathrm{www}$. facebook.com/resistenciaesolidariedademcr.

${ }^{6}$ https://sites.google.com/view/prcontracovid/mapa-da-solidariedade.

${ }^{7}$ Para organizar as informações agrupamos as ações de solidariedade em três grandes grupos de mesorregiões: 1) Parte Norte: Norte Pioneiro, Norte Central e Noroeste; 2) Parte Oeste: Centro Ocidental, Oeste, Sudoeste e Centro-Sul; 3) Parte Leste: Sudeste, Metropolitana de Curitiba e Centro Oriental.
} 
EM

QUESTÃO

V.13 N. $03 \bullet 2020$

pág. 179-201

Paranaense), respetivamente. Para além das quantidades e dos locais, nos parece fundamental reforçar dois ensinamentos fundamentais: que todo esse processo escancara a necessidade de entender a questão agrária no estado e que não se trata de um esforço de caridade ou doação de migalhas que, não raro, afrontam a justiça enquanto princípio inalienável e fim inadiável. Cientes de que "solidariedade é compartilhar o que temos, e não o que nos sobra" (HADICH, 2020) os sujeitos e as sujeitas que promovem essas ações se empenham na construção de verdadeira justiça social pelas próprias mãos calejadas.

\section{Solidariedade em campo: panorama no Paraná}

Em 155 dias entre a primeira e a última ação de solidariedade aqui considerados foram entregues $429.870 \mathrm{~kg}$ de comida no Paraná, ou seja, uma média de 2.773,35 kg de alimentos diários. As camponesas e camponeses de 54 acampamentos, 123 assentamentos, 21 comunidades de faxinalenses, posseiros, unidades de produção da agricultura familiar, escolas de agroecologia, cooperativas e sindicatos de trabalhadores rurais de 81 municípios distribuídos em todas as regiões do estado fizeram chegar gratuitamente uma parte da sua produção para bairros periféricos, ocupações urbanas, hospitais públicos e Santas Casas, asilos de idosos, associações de moradores e de catadores, abrigos, pessoas em situação de rua e comunidades indígenas.

Nesse período foram doadas 19.000 marmitas agroecológicas, 600 máscaras de tecido, 60 litros de álcool 70\%, além de 80 tipos de alimentos entre grãos, tubérculos, frutas, legumes, verduras, mel, ovos, pães, bolachas, leite, bebida láctea, queijo e macarrão caseiro. A Figura 1 apresenta a espacialização de tão extraordinária obra que, por ora, resultou na dádiva de quase 500 toneladas de alimentos produzidos no chão da reforma agrária.

Figura 1 - Ações de solidariedade no Paraná coordenadas pelo MST (por Mesorregiões).

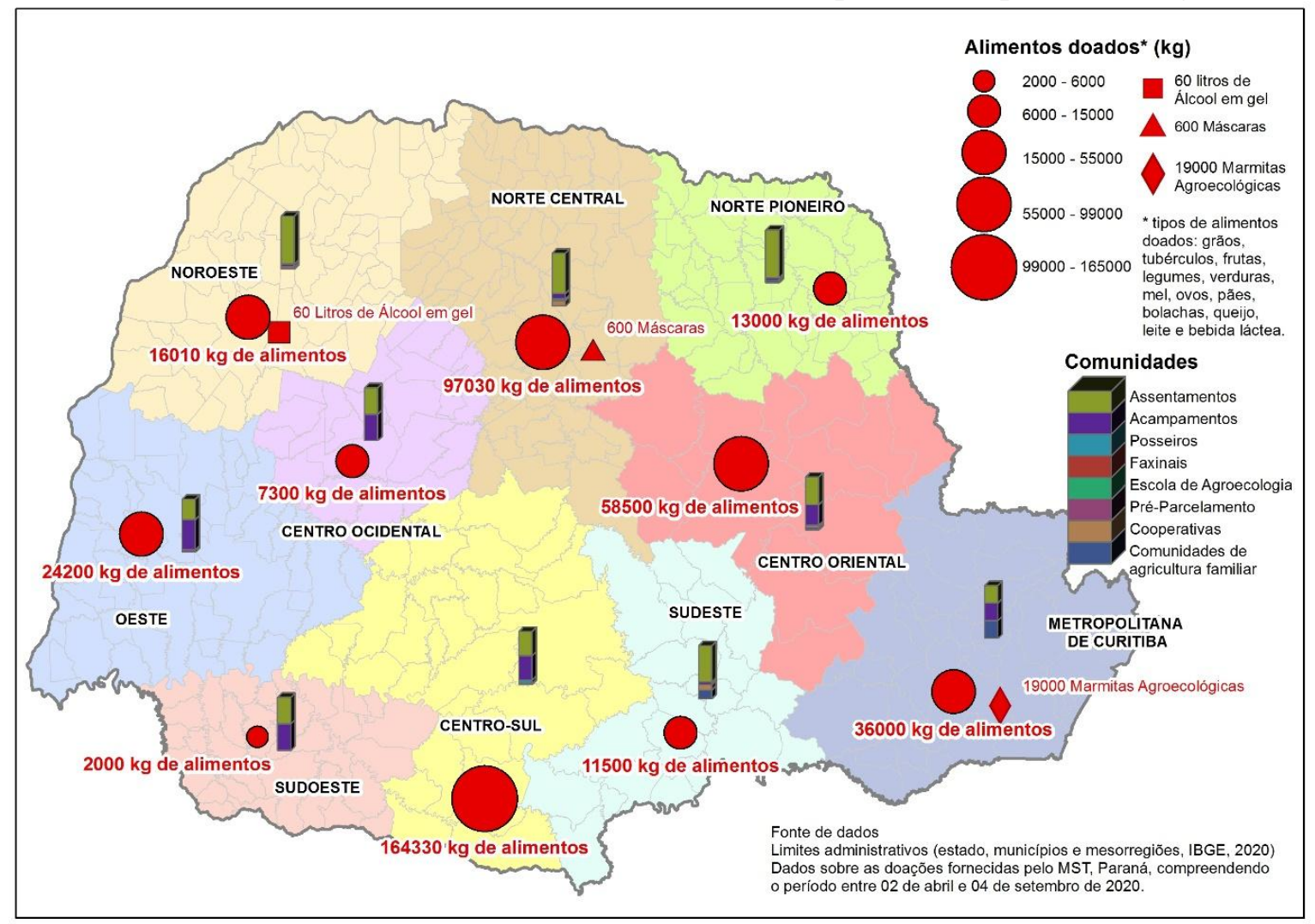

Fonte: MST-Paraná. Org: autores. 
EM

QUESTÃO

V.13 N. $03 \bullet 2020$

pág. 179-201

\section{Parte Norte}

Considerando a divisão do IBGE em mesorregiões, a porção setentrional do estado está representada pelo noroeste, norte central e norte pioneiro, onde muitas famílias ainda permanecem acampadas, mas a solidariedade foi mais forte que a privação dolorosa imposta pelo latifúndio em associação com o Estado, que teima em negar-lhes o acesso à terra de trabalho. Em Centenário do Sul, no acampamento Fidel Castro, há um exemplo notável: o Centro de Produção de Alimentos Saudáveis Antônio Tavares, retratado na Fotografia 1, é um território de (re) existência onde floresce abundância de comida e de solidariedade.

Fotografia 1 - Produção de alimentos saudáveis mantém as doações no norte-central paranaense.

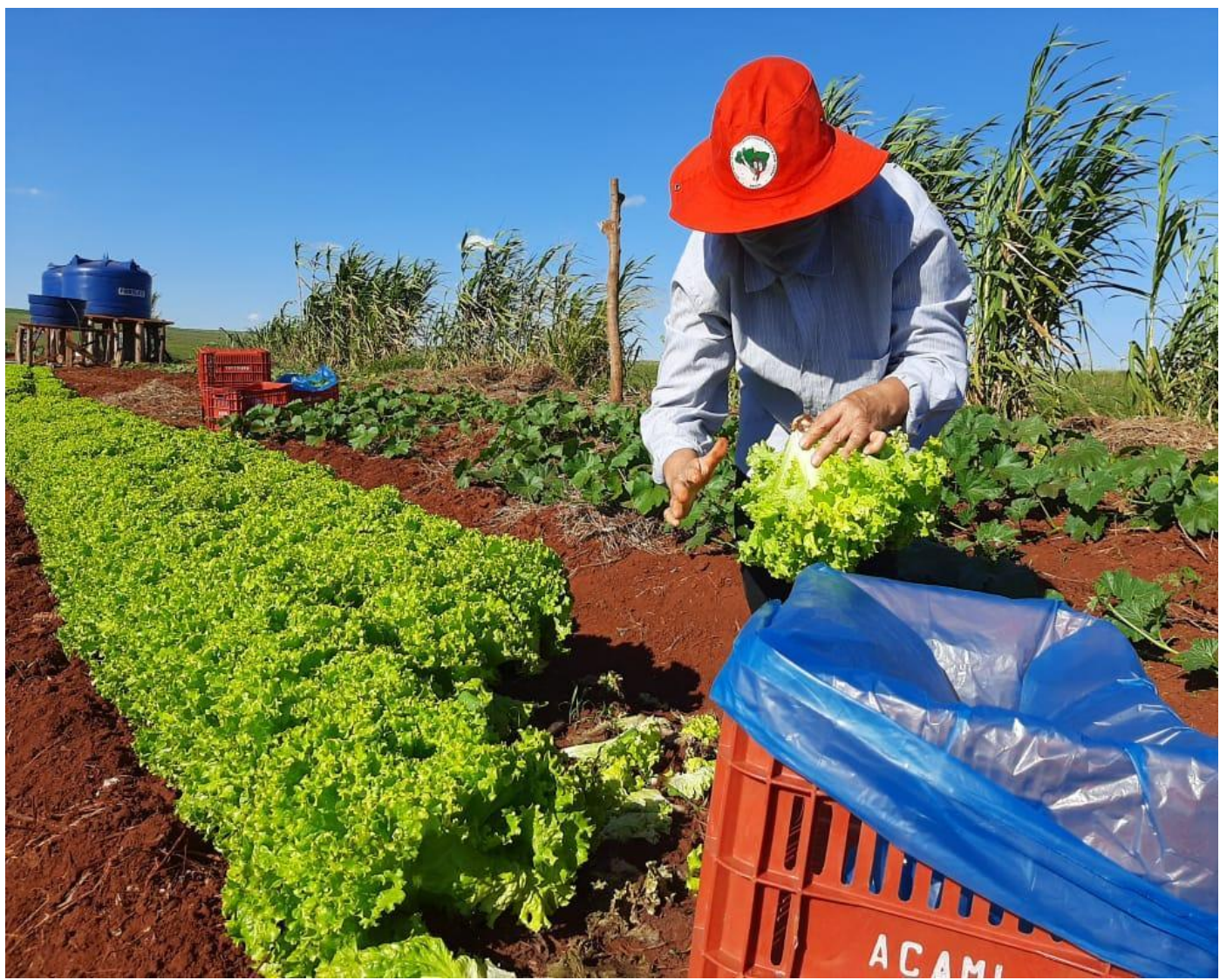

Foto: Erika Bueno Aguiar, 19/06/2020.

De fato, boa parte dos alimentos e mantimentos doados na região norte central foram provenientes de acampamentos. Apesar destes estarem marcados pela precariedade em diversos aspectos, como moradia que, muitas vezes, se resume a barracos de lona preta, acesso à água e energia elétrica, disponibilidade de um pedaço de terra para plantar, também são espaços de organização e enfrentamento coletivo das dificuldades. Por isso, se criam sistemas como a Quartinha, que consiste no fracionamento do terreno em lotes de 40 x 40 metros de terreno para cada família enquanto a divisão definitiva dos lotes não vem, e isso pode durar mais de uma década. O que poderia se traduzir em espaços de derrota ou resignação, se transforma em espaços de esperança, solidariedade e fartura, a exemplo do registrado no Acampamento Maila Sabrina, em Ortigueira (Fotografia 2). 
EM

QUESTÃO

V.13 N. $03 \bullet 2020$

pág. 179-201

Fotografia 2 - Organizando os alimentos para doação.

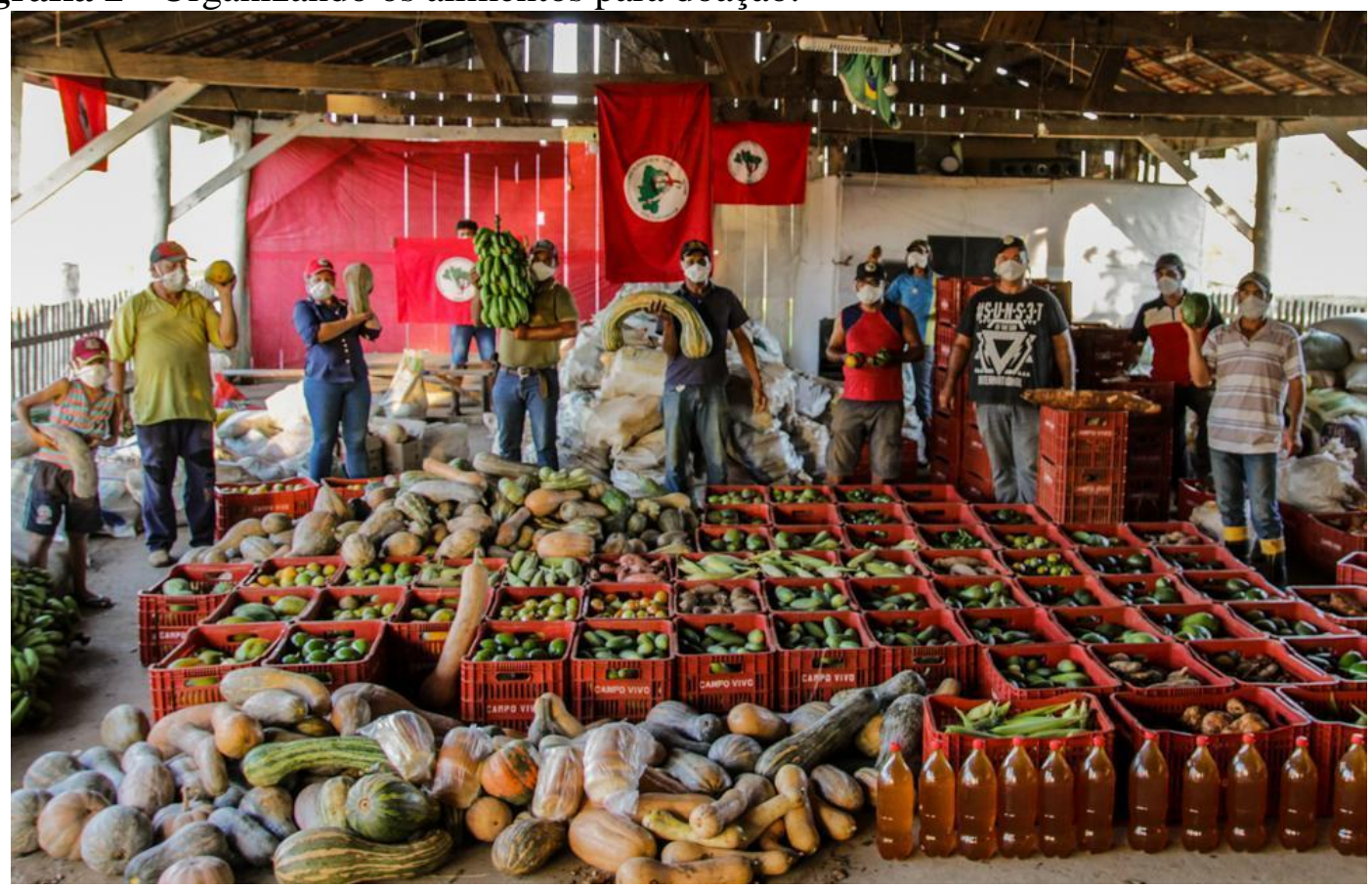

Foto: Lia Bianchini, 14 de abril de 2020.

A região norte central cooperou com 97.030 quilos. Em um único dia, 20 de junho, foram distribuídos 44.850 quilos de alimentos a famílias moradoras de bairros periféricos de Londrina, como mostra a Fotografia 3.

Fotografia 3 - 11 comunidades do MST na entrega dos frutos da reforma agrária.

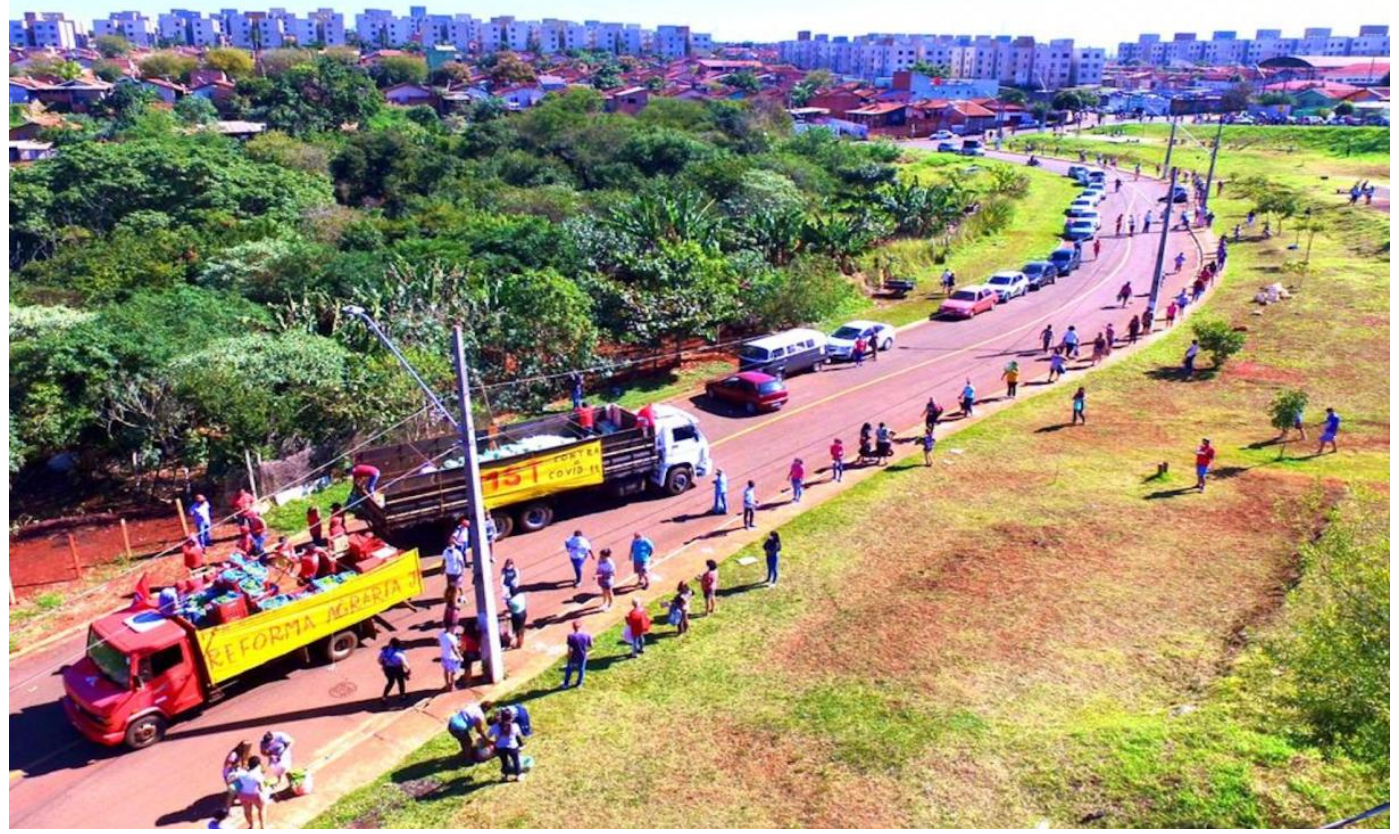

Foto: Wellington Lenon, 20/06/20.

Já do acampamento Maila Sabrina, em Ortigueira, saíram 29.000 quilos entregues em Curitiba. Ao todo, a região chegou a quase $30 \%$ de tudo o que o MST distribuiu no Paraná. 
EM

Uma façanha que só foi possível com o envolvimento de outros acampamentos que também fizeram o esforço da partilha, como o Herdeiros da Luta de Porecatu, o Zilda Arns e o Manoel Jacinto Correia, de Florestópolis, o Fidel Castro, de Centenário do Sul, o Carlos Marighella em Congoinhas e o Padre Josimo, de Cruzeiro do Sul, além de um conjunto de assentamentos da região que, se bem desfrutam de uma maior segurança sobre a terra em que vivem, ainda amargam infraestruturas precárias, solos de baixa qualidade, pouco acesso a crédito e quase nenhuma assistência técnica: Eli Vive (Londrina); Dorcelina Folador (Arapongas); Companheiro Keno (Jacarezinho); Iraci Salete (Alvorada do Sul); Nova Itaúna (Manoel Ribas); Ho Chi Minh, Carlos Lamarca, Robinson de Souza e Rosa Luxemburgo (Congonhinhas); Novo Horizonte (Santo Inácio-Cafeara); Santa Maria-COPAVI (Paranacity); Milton Santos (Planaltina do Paraná); Companheira Roselí Nunes (Amaporã), Nossa Senhora Aparecida (Mariluz), Antonio Tavares, Che Guevara, Margarida Alves, Luiz Carlos Prestes, Santiago da Maia e Pontal do Tigre (Querência do Norte); 17 de Abril e Paraná (Santa Cruz de Monte Castelo); Ilgo Luz Peruzzo (Santa Mônica); Mãe de Deus (Jardim Olinda); Taperivá (São João do Caiuá); Maria Lara (Centenário do Sul); Florestan Fernandes (Florestópolis); Mascote, Salete Strozake e União Santa Adélia (Itaguajé); 8 de abril (Jardim Alegre); Nova Itaúna (Manoel Ribas); Barra Bonita (Primeiro de Maio); Norte Sul e Novo Horizonte (Santo Inácio); Água da Prata, Cacique, Comanche, Cruz de Malta, Serraria, Tesouro e União Camponesa (Tamarana); Elias de Meura (Carlópolis); Nango Vive (Jundiaí do Sul); Amélia, Arixiguana, Cacique Cretã, Dom Hélder, Jucape, Palmares, Paulo Freire, Roseli Nunes, Sol Nascente (São Jerônimo da Serra); Boa Esperança, Bom Sucesso, São Luis 2 e comunidade Lambari (Sapopema); e Escola Milton Santos (Maringá).

Fotografia 4 - Solidariedade e coordenação da produção à entrega.

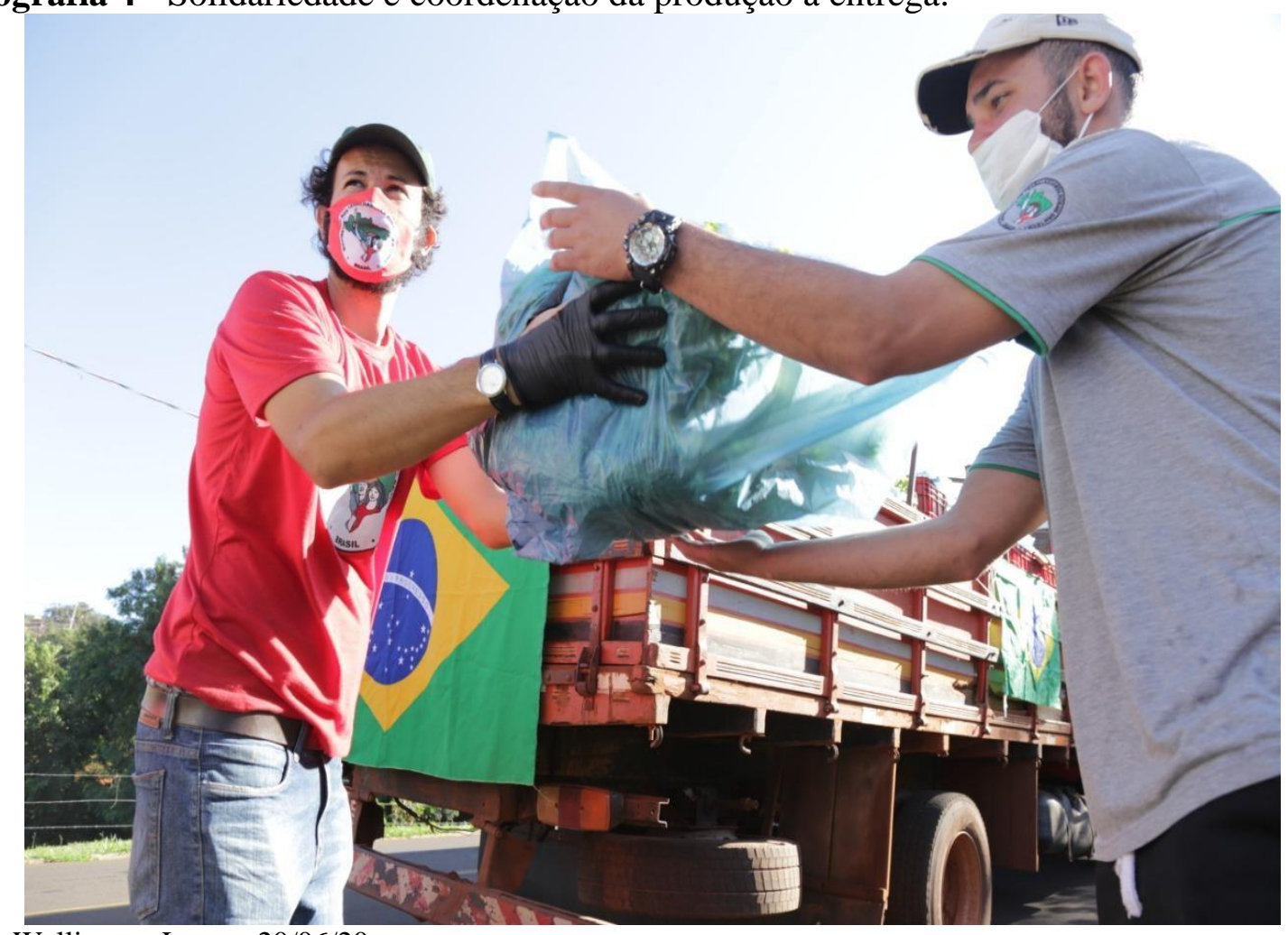

Foto: Wellington Lenon, 20/06/20.

A solidariedade não é um aprendizado novo nesses lugares. Entre as moradoras e moradores de assentamentos e aquelas e aqueles que ainda sofrem as incertezas dos acampamentos, existe uma disposição para a união que reafirma: enquanto houver um sem 
EM

QUESTÃO

V.13 N. $03 \bullet 2020$

pág. 179-201

terra, nós também o seremos. Ainda em dezembro do ano passado, a Associação de Mulheres Camponesas (AMCEV) do assentamento Eli Vive, foi um dos coletivos que saíram em socorro aos sem terra do Acampamento Reduto Vitória do Contestado, em General Carneiro, região Centro-Sul do estado.

Esse é só um exemplo dos valores cultivados dentre os que lutam pela justa distribuição da terra, porque dela emana toda forma de justiça. Nos momentos de grandes dificuldades e falta de soluções, como o que vivemos atualmente, esse espírito de união está sendo compartilhado com aquela parte da sociedade que mais precisa, ainda que ela não faça parte da reforma agrária. Depois de conhecer tão de perto o que é a fome, dividem a alegria de produzir o próprio alimento, na festa ímpar de solidariedade, reciprocidade e ajuda mútua.

Fotografia 5 - AMCEV presente na doação de alimentos.

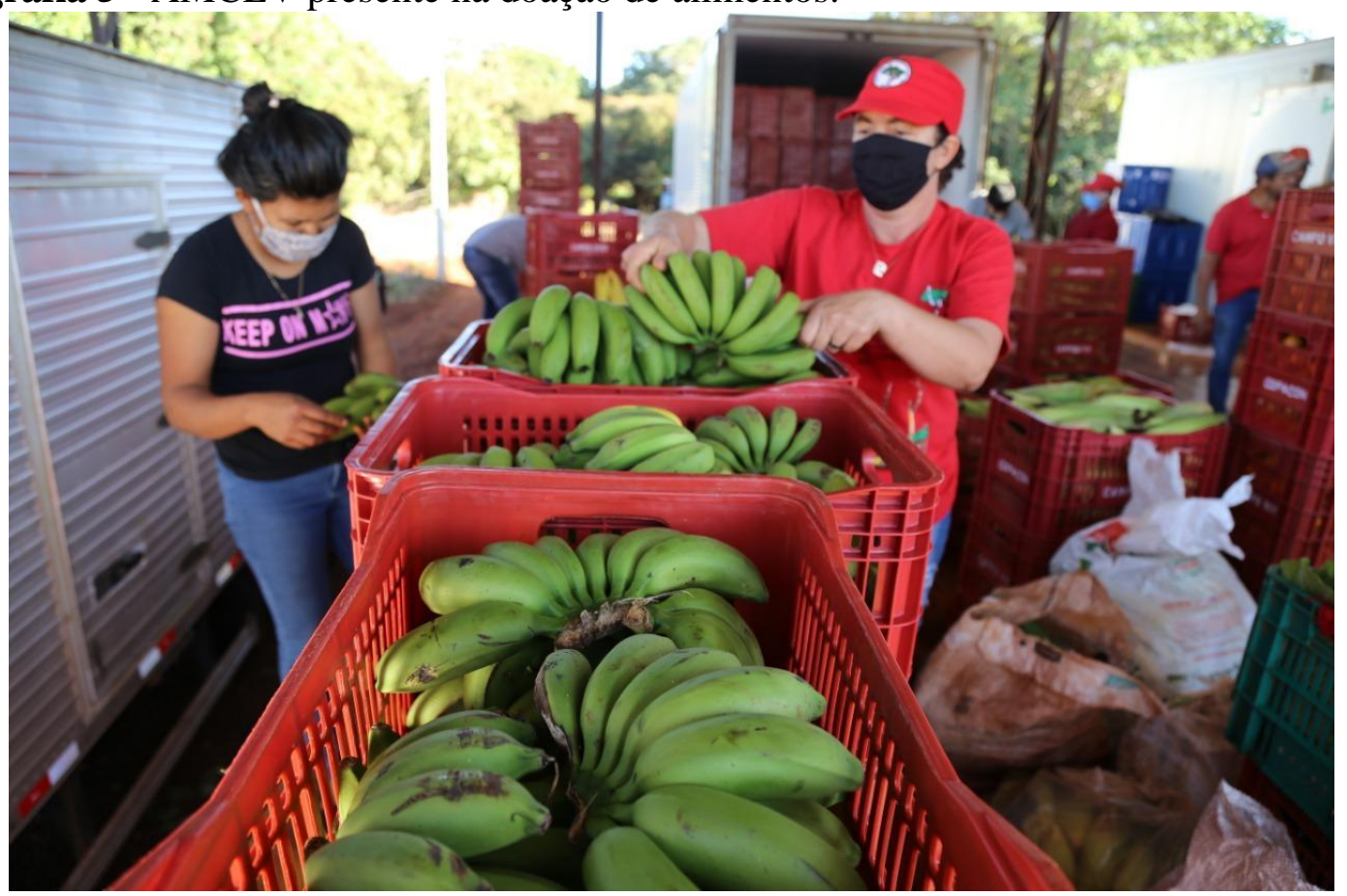

Foto: Wellington Lenon, 20/06/20.

\section{Parte Oeste}

Numa mirada regional, verifica-se que na mesorregião Oeste do Paraná, mesmo com vários acampamentos ameaçados de despejo, os camponeses do MST têm se organizado e já realizaram a doação de $24.200 \mathrm{~kg}$ de alimentos a hospitais, entidades assistenciais, abrigos, comunidades em situação de vulnerabilidade social e comunidades indígenas. A vivência com estes sujeitos exprime a dimensão da solidariedade no contexto da carência, já que a partilha não diz respeito apenas a produtos, mas também a trajetórias. 
EM

QUESTÃO

V.13 N. $03 \bullet 2020$

pág. 179-201

Fotografia 6 - Alimento da partilha no assentamento Valmir Mota, de Cascavel.

Foto: Eliana de Oliveira, 17/04/20.

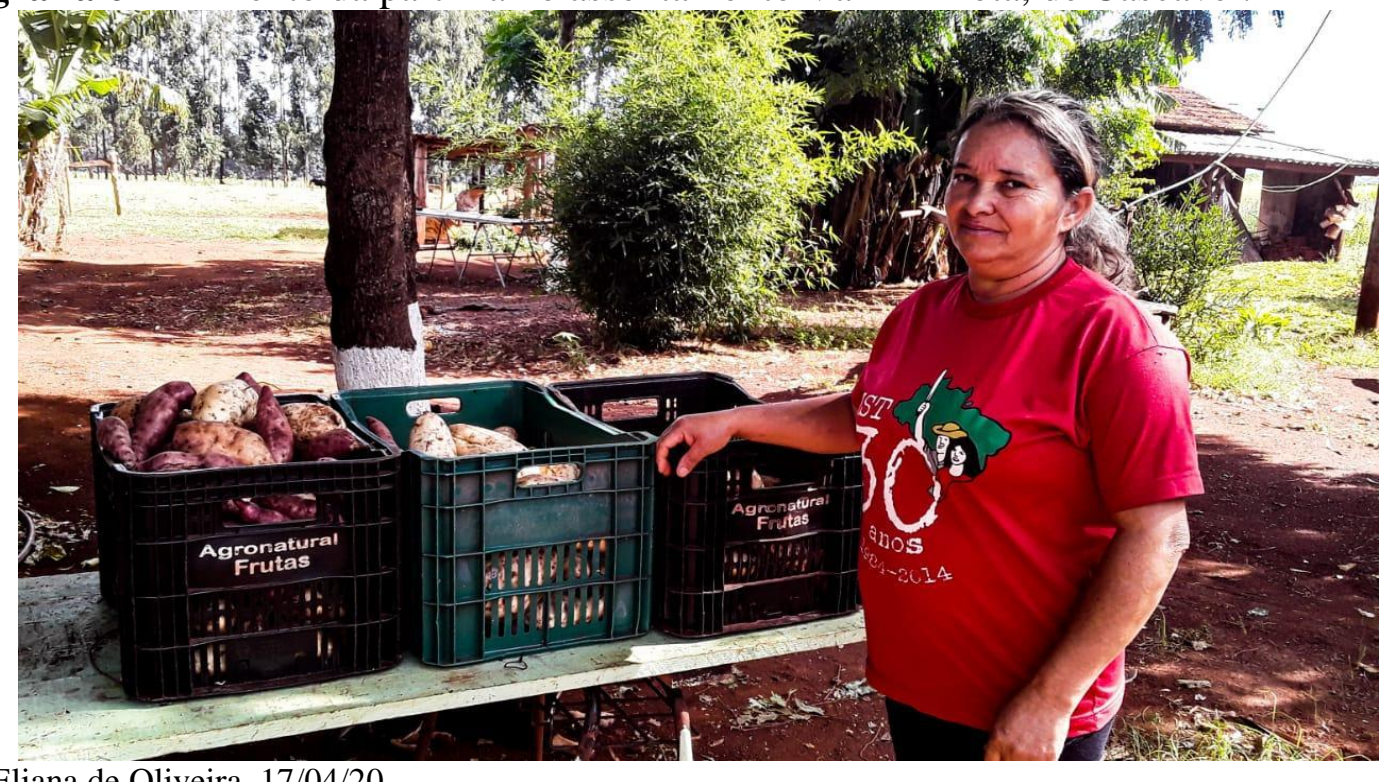

Dentre as ações, merece destaque a doação de duas toneladas de alimentos às comunidades indígenas de Guaíra e Terra Roxa (Fotografia 7), cujo despojo territorial está na raiz de vulnerabilidades extremas, sem falar na coerção exercida pelos que se apropriaram daquilo que é um patrimônio ancestral e que, na letra da lei, seria intransferível. As retomadas são o que melhor expressa a convergência entre a luta pela terra e a luta pelo território. A primeira vislumbra a política de reforma agrária como caminho para a terra distribuída, onde a família é a célula da qual emana a organização do trabalho e da vida social. A segunda subsume a unidade territorial como condição para a reprodução comunitária, célula em torno da qual se dá o (auto)reconhecimento.

Aquilo que formalmente parece contraposição, qual seja superfície parcelar para o campesinato e território indivisível para o indigenato, concretamente expressa unidade na diversidade, pois esses sujeitos lutam pela terra para nela realizar o trabalho próprio, escapando assim às formas de exploração a que estão sujeitos pelo império dos negócios que não podem prescindir desse despojo.

Fotografia 7 - Alimentos da luta camponesa para a luta indígena do Oeste do Paraná.

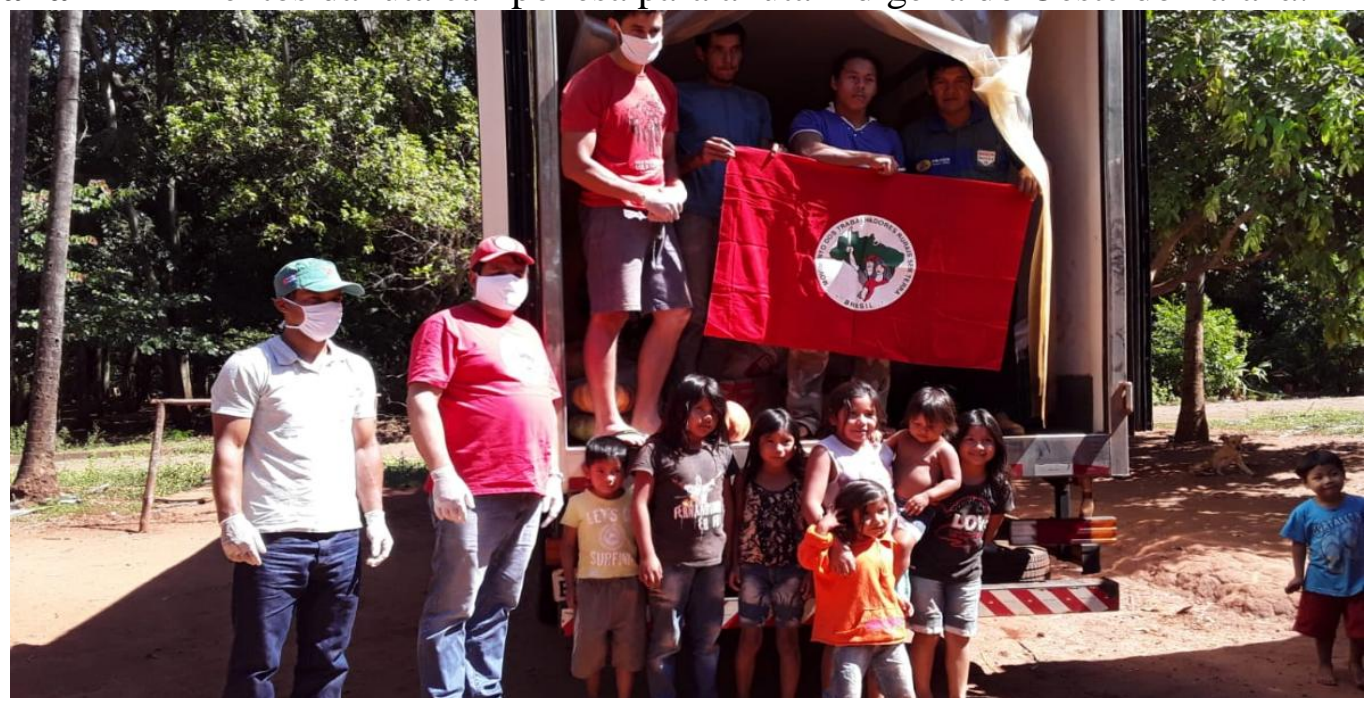

Foto: Eliana de Oliveira, 10/04/20. 
EM

Comunidades carentes de diversos municípios do Oeste do Paraná também receberam doações das famílias que, precária ou institucionalmente, conseguiram acessar a terra de plantar. De Cascavel, foram os acampados e acampadas do Primeiro de Agosto e do Resistência Camponesa, bem como os assentados e assentadas do Valmir Mota, que partilharam seus frutos. As famílias assentadas no Olga Benário e Sepé Tiaraju de Santa Tereza do Oeste e os camponeses e camponesas acampados no Nova Semente, em Catanduvas, também fizeram parte desta iniciativa cujo valor não se mede em quilos.

Em 17 de abril de 1996 ocorreu o massacre de Eldorado dos Carajás. Contra a perpetuação da barbárie como aquela ali perpetrada, essa data tornou-se o marco da luta e da denúncia da violência contra os camponeses. Nesse que passou a ser o dia Internacional da Luta Camponesa, o MST organizou a doação de quatro toneladas de alimentos para hospitais, albergues, asilos, entidades que abrigam pessoas em situação de rua e comunidades carentes dos municípios da região Oeste. O compromisso social foi possível com a participação dos acampamentos Primeiro de Agosto, Dorcelina Folador, Resistência Camponesa (Cascavel), Nova Semente (Catanduvas) e Mãe dos Pobres (Matelândia), e dos assentamentos Valmir Mota (Cascavel), Olga Benário e Sepé Tiaraju (Santa Tereza do Oeste).

Fotografia 8 - O 17 de abril deste ano foi dia de solidariedade em Santa Tereza do Oeste.

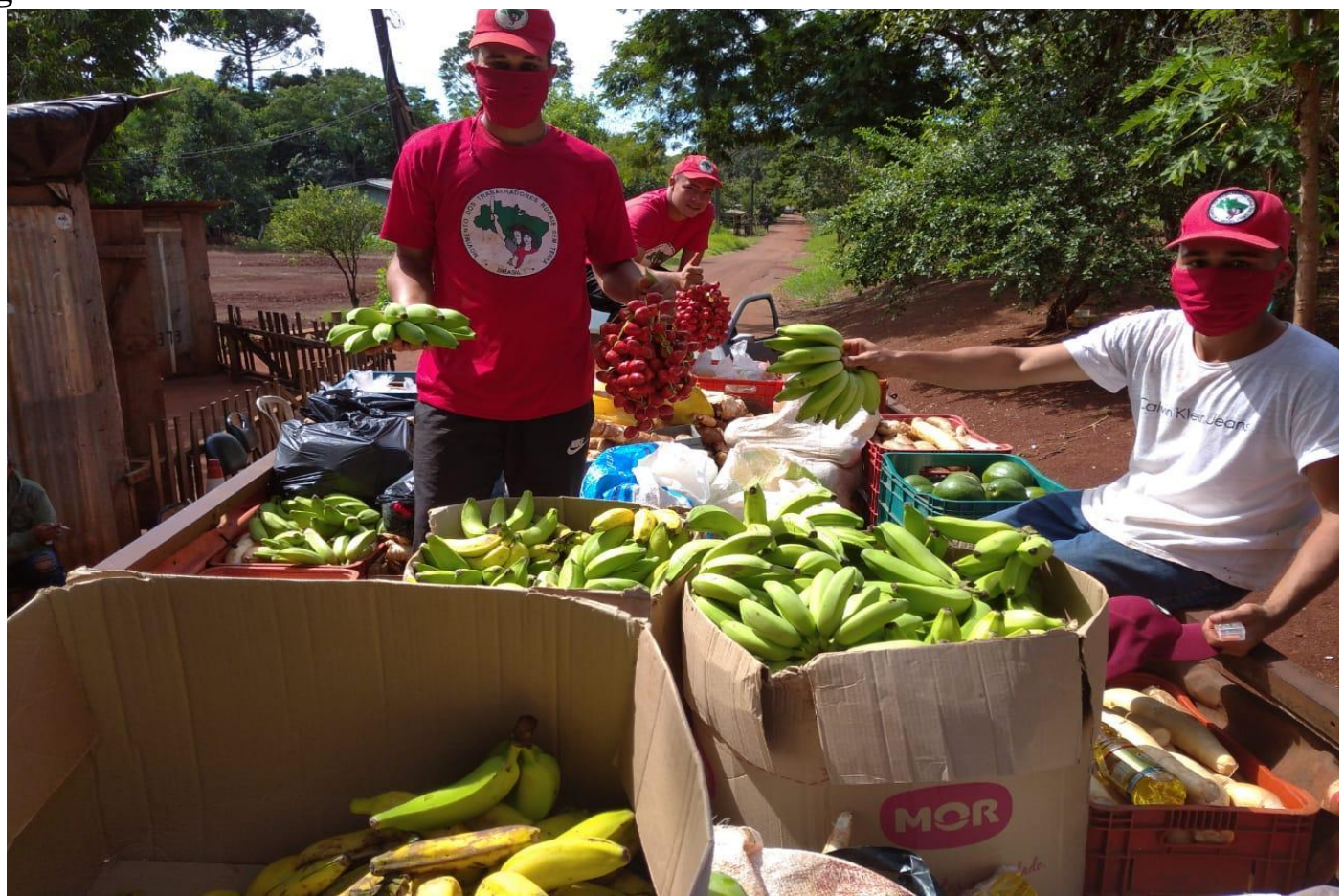

Foto: Marilene Hammel, 04/06/20.

No dia 02 de maio, em homenagem a Antônio Tavares, camponês assassinado há 20 anos pela polícia militar do estado do Paraná nas proximidades de Curitiba, os camponeses do assentamento Antônio Companheiro Tavares e do acampamento Sebastião Camargo, ambos do município de São Miguel do Iguaçu, doaram uma tonelada de alimentos à famílias do respectivo município. Em 05 de junho, dia Mundial do Meio Ambiente, os camponeses do MST na região Oeste do Paraná doaram mais 13 toneladas de alimentos a diversas entidades assistenciais da respectiva região e a 700 famílias do município de Cascavel.

A solidariedade só foi possível com a dedicação das famílias dos acampamentos Primeiro de Agosto, Dorcelina Folador e Resistência Camponesa (Cascavel); Nova Semente (Catanduvas), Sebastião Camargo (São Miguel do Iguaçu), Chico Mendes (Ibema), Padre 
EM

QUESTÃO

V.13 N. $03 \bullet 2020$

pág. 179-201

Josimo e Chico Mendes (Matelândia), dos assentamentos rurais Valmir Mota e Santa Terezinha (Cascavel); Antônio Companheiro Tavares (São Miguel do Iguaçu), Santa Isabel e 16 de Maio (Ramilândia); Ander Rodolfo Henrique (Diamante do Oeste), Olga Benário e Sepé Tiaraju (Santa Tereza do Oeste) e do pré-parcelamento 28 de Outubro do município de Ramilândia.

Fotografia 9 - A qualidade de $13.000 \mathrm{~kg}$ de alimentos para doações em Cascavel sob o crivo das camponesas.

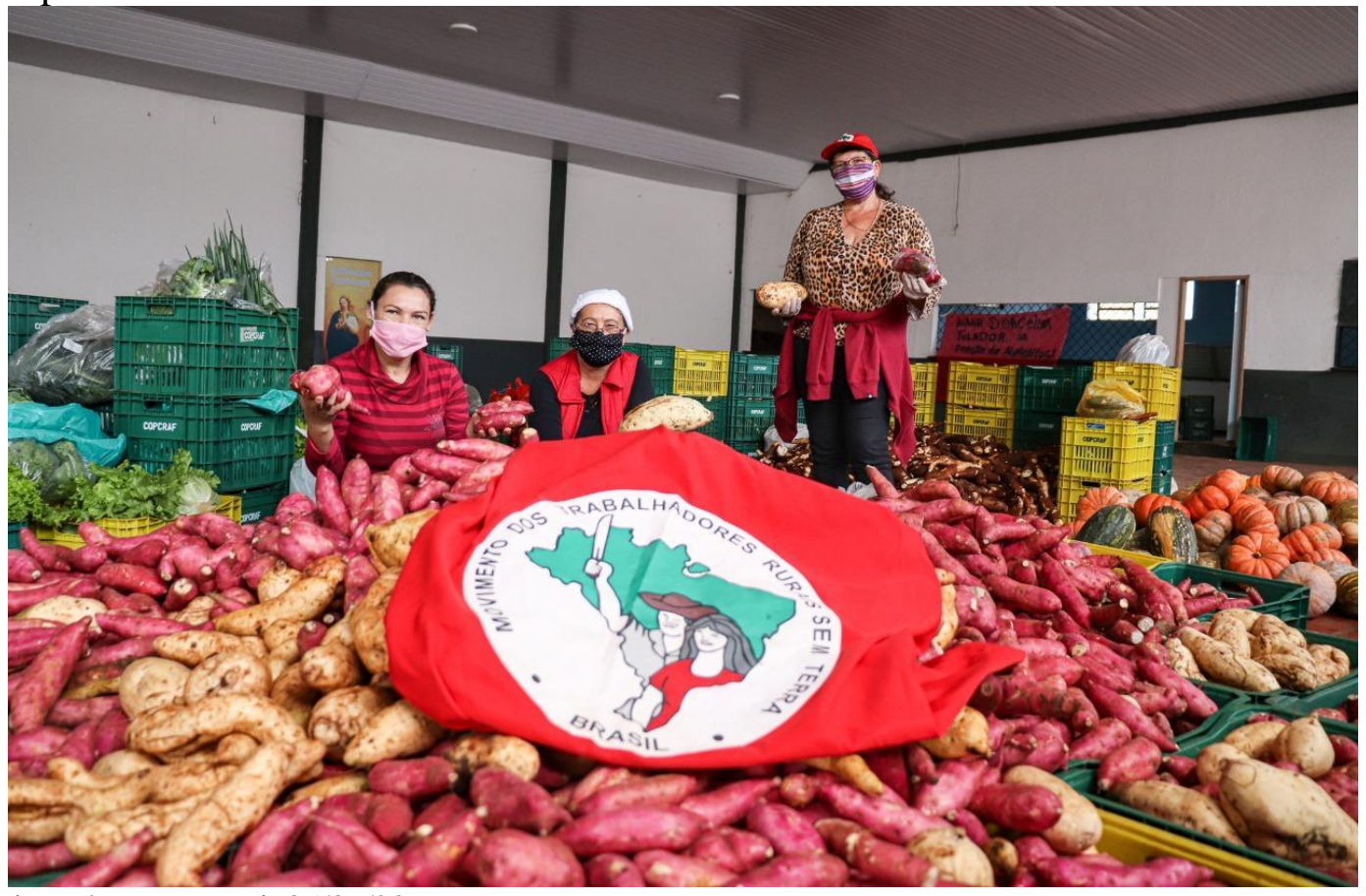

Foto: Diangela Menegazzi, 05/06/20.

Dentre os alimentos doados encontram-se grãos, tubérculos, frutas, legumes, verduras, mel, entre outros. Destaca-se ainda que a maior parte destes são produzidos de forma agroecológica, garantindo assim o acesso à alimentação saudável a várias famílias em situação de vulnerabilidade nas áreas periféricas das cidades e em comunidades indígenas. Importante registrar que tudo provém do trabalho desses agricultores e agricultoras, daquilo que eles produziram para alimentar suas famílias. Porém, com a clareza de seu papel social, partilham o bem mais precioso que possuem, o alimento.

Importante registrar que oito assentamentos rurais e nove acampamentos de camponeses sem-terra participaram das ações de arrecadação e doação de alimentos na região Oeste do Paraná. Dentre os acampamentos, as comunidades Resistência Camponesa, Dorcelina Folador e Primeiro de Agosto localizadas no município de Cascavel, possuem mandatos de reintegração de posse ${ }^{8}$. Ou seja, mesmo diante de incertezas e injustiças, estas camponesas e camponeses não deixam de partilhar aquilo que possuem em prol da justiça social. A preocupação com a vida e com o cuidado são postos enquanto perspectiva central de recomposição da sociedade.

\footnotetext{
${ }^{8}$ Suspensos temporariamente em decorrência da pandemia.
} 
EM

QUESTÃO

V.13 N. $03 \bullet 2020$

pág. 179-201

Fotografia 10 - Preparação dos alimentos no acampamento Chico Mendes, de Matelândia a serem entregues ao hospital do município.

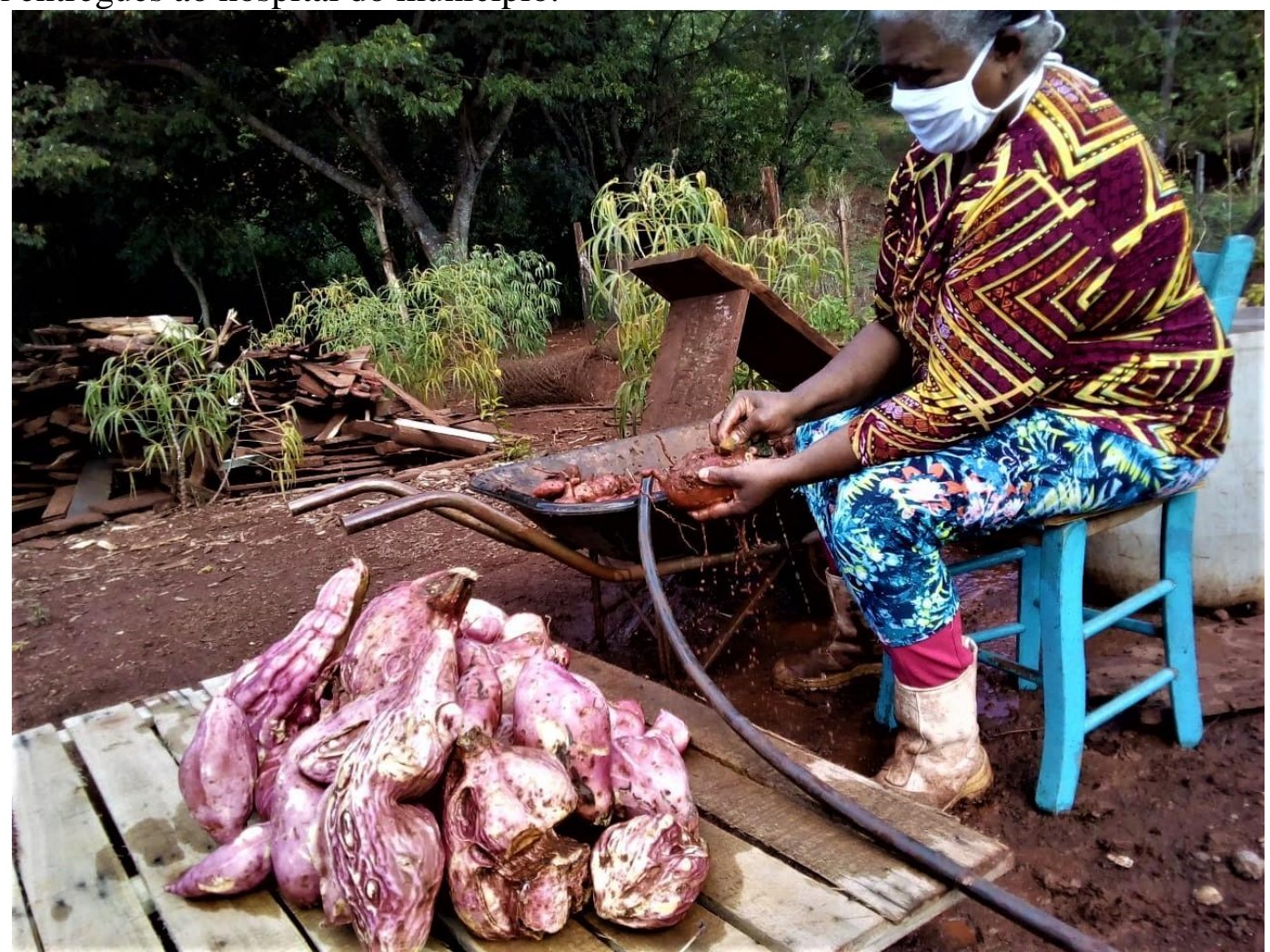

Foto: Arquivo do MST.

Com o mesmo propósito de colocar-se a serviço dos menos assistidos, procuram resistir e enfrentar a crise que é oriunda, fundamentalmente, da luta de classes. Os camponeses do MST das regiões Sudoeste e Centro-Ocidental doaram $9.300 \mathrm{~kg}$ de alimentos, fato possível pela organização e partilha das famílias dos acampamentos Valdair Roque (Quinta do Sol), Irmã Dorothy (Barbosa Ferraz), Monte Alto (Peabiru), Sete de Setembro e São Francisco de Assis (Renascença); e dos assentamentos Eduardo Raduan e João de Paula (Marmeleiro), Luz (Luiziana), Santa Rita (Peabiru) e Roncador (Quinta do Sol).

No Centro-Sul, a resistência também se fez por meio de ações de solidariedade. Dos acampamentos, assentamentos, comunidades de faxinais e de posseiros desta região veio a expressiva partilha de $164.330 \mathrm{Kg}$ de alimentos. Nestas ações participaram ativamente 26 acampamentos de camponeses sem terra: Dom Tomás Balduíno, Fernando de Lara, Leonir Orbak e Vilmar Bordin (Quedas do Iguaçu); Terceira Conquista (Espigão Alto do Iguaçu); Herdeiros da Luta de Primeiro de Maio e Antônio Conrado (Rio Bonito do Iguaçu); Recanto da Natureza (Laranjeiras do Sul); São Domingos, Dezenove de Abril e União (Inácio Martins); Encontro das Águas e Gerônimo (Guarapuava); Terra Livre e Mãe dos Pobres (Clevelândia); Claudete Vive (Boa Ventura do São Roque); Nova Aliança, Poço Grande, Filhos da Terra, Mato Branco, Nova Esperança, Cinco de Maio, Nossa Senhora de Aparecida, São Sebastião e São Roquinho (Pinhão); Porto Pinheiro (Porto Barreiro); e 05 comunidades faxinalenses e de posseiros: Comunidade Faxinalense São Roquinho e comunidades de posseiros Alecrim, França, Frech e Bugil (Pinhão) o que evidencia que embora haja precariedades materiais e inseguranças com relação ao acesso à terra, brotam destes espaços capacidade de organização, formulação de estratégias, resiliência e solidariedade para os que estão enfrentando dificuldades. 
EM

Há que se destacar ainda que entre as comunidades que se organizaram e doaram alimentos está a dos posseiros do Alecrim, a qual sofreu despejo violento e repentino no dia 01 de dezembro de 2017. Naquele dia, as 20 famílias que ocupavam a área perderam tudo, pois nem tempo para retirar pertences pessoais foi possibilitado. Até mesmo estruturas comunitárias construídas ao longo de mais de 20 anos em que ocupavam as terras foram destruídas com o uso de tratores e máquinas. Uma semana após o trágico acontecimento as famílias ocuparam novamente a área e, mesmo diante de tanta violência sofrida, em maio de 2020 deram exemplo, partilhando os frutos do seu trabalho e exercitando a solidariedade, valor fundamental para a humanidade.

Fotografia 11. Coragem, força e solidariedade às costas no acampamento Encontro das Águas, em Guarapuava.

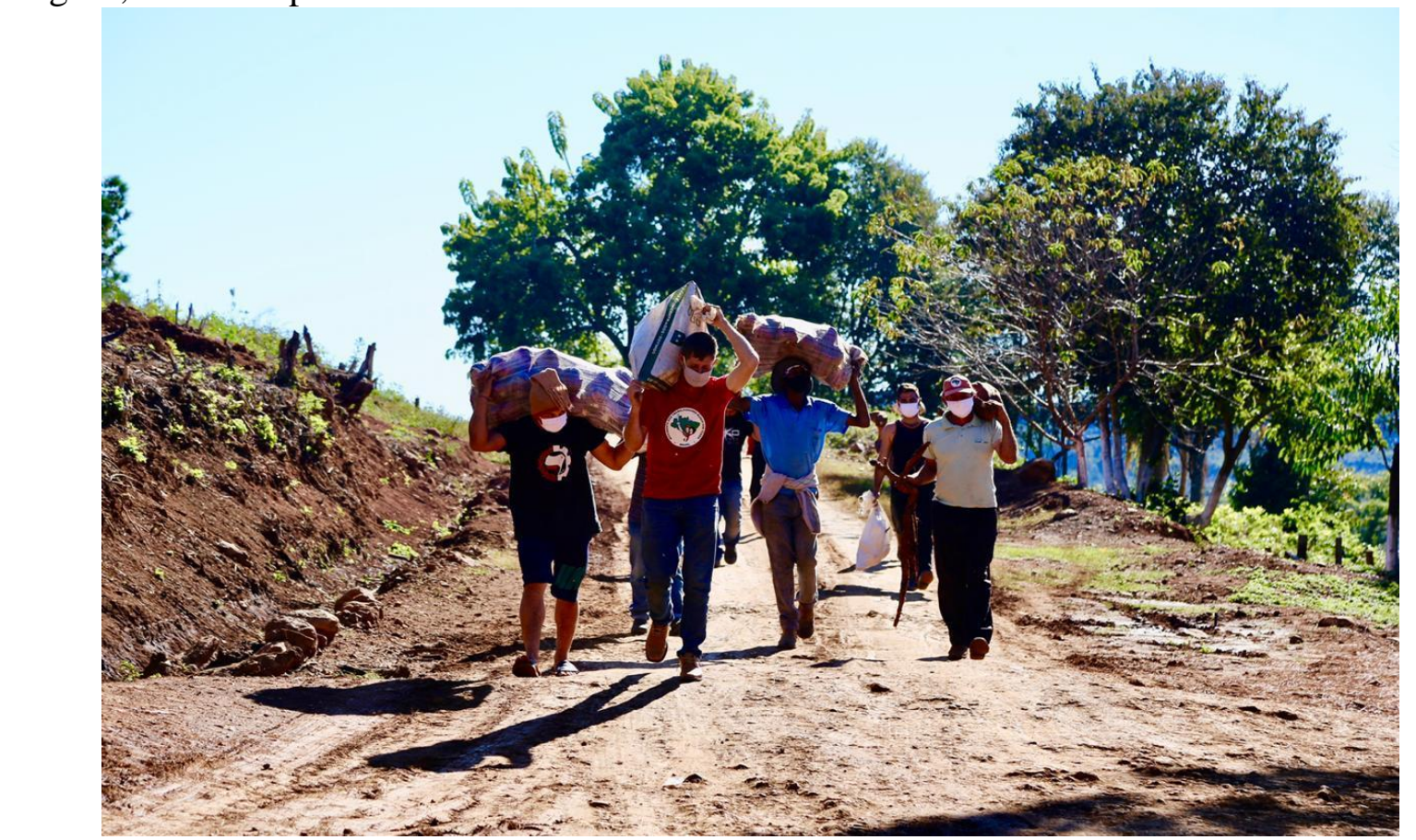

Foto: Wellington Lennon, 30/05/20.

Não menos importante nesse contexto é a contribuição dos 27 assentamentos rurais dessa mesorregião Centro-Sul: Oito de Junho e Passo Liso (Laranjeiras do Sul), Celso Furtado e Rio Perdido (Quedas do Iguaçu), Novo Paraíso (Boa Ventura do São Roque), Nova Geração, Europa, Rosa, Banana e Treze de Novembro (Guarapuava); Ouro Verde, Jarau e Juquiá de Cima (Cantagalo); Nossa Senhora da Vitória, Jaboticabal e Vinte e Nove de Agosto (Goioxim), Ilha do Cavernoso (Candói); Conquista da Bracatinga (Espigão Alto do Iguaçu); Chapadão e Conquista Camponesa (Laranjal); Estrela e Terra Livre (Nova Laranjeiras); Cascata (Pitanga); Dez de Maio, Ireno Alves dos Santos e Marcos Freire (Rio Bonito do Iguaçu); e, Araguaí (Santa Maria do Oeste). Embora sofram com a falta de uma política de Estado efetiva de reforma agrária, resistem e mostram a importância do acesso à terra para que os camponeses possam abastecer a sociedade com alimentos saudáveis e de qualidade. 
EM

QUESTÃO

V.13 N. $03 \bullet 2020$

pág. 179-201

Fotografia 12. Doação de 50 toneladas de alimentos em Guarapuava e Pinhão.

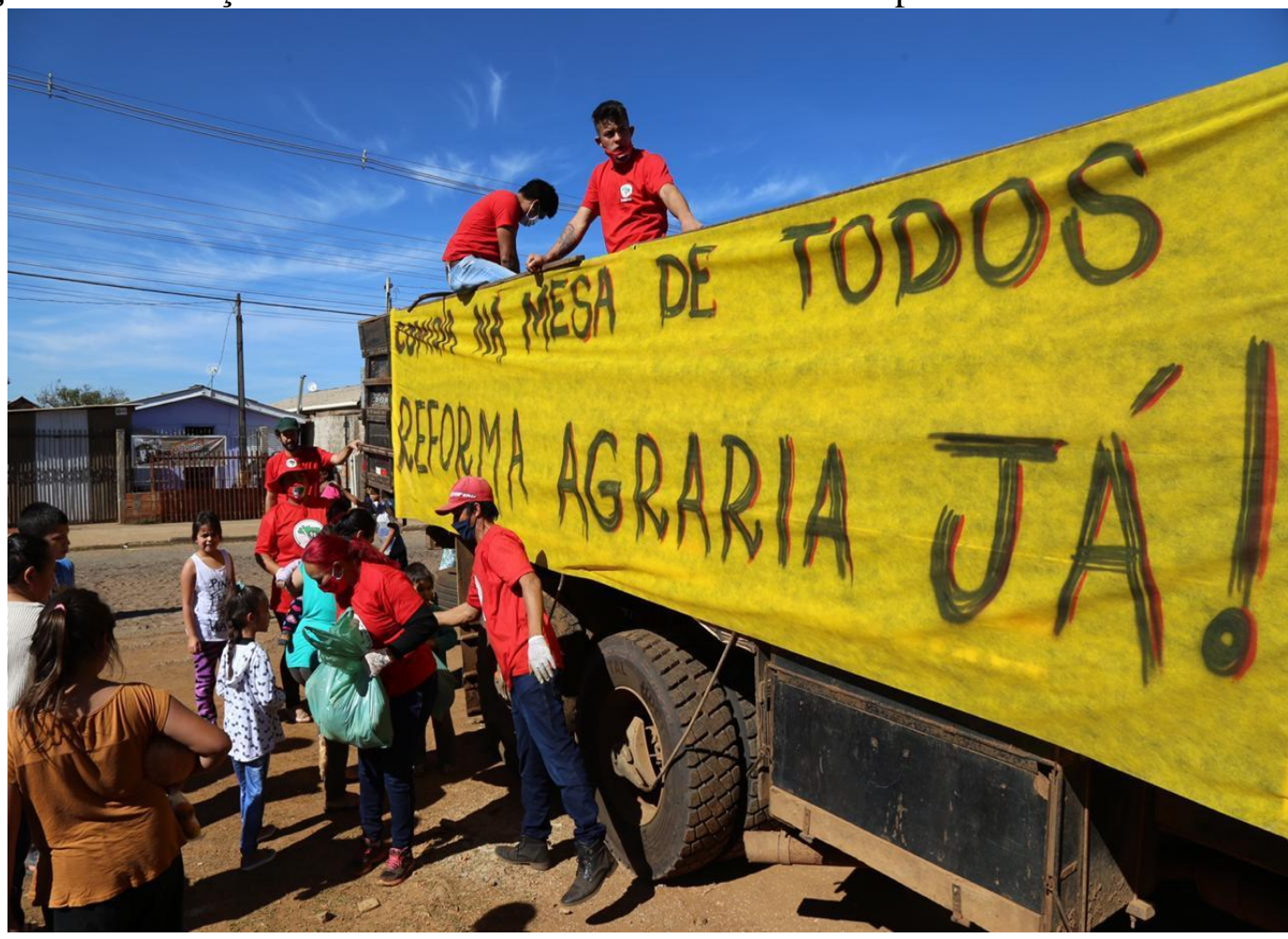

Foto: Wellington Lennon, 30/05/20.

Portanto, nunca é demasiado reafirmar a importância e necessidade histórica da reforma agrária para dirimir as injustiças sociais cristalizadas no pandemônio estrutural do latifúndio.

\section{Parte Leste}

"Se o campo não roça, a cidade não almoça! Se campo não planta a cidade não janta!" São palavras de ordem há anos ecoando nas manifestações a favor da reforma agrária, da agroecologia e da soberania alimentar. Um alerta à insustentabilidade das cidades e da potência da terra dividida no campo. As ações de solidariedade em todo o Paraná têm mostrado que as relações campo-cidade são mais estreitas do que pensamos, sobretudo quando as dificuldades recrudescem.

Curitiba mostra claramente essa situação: desde abril, $67.000 \mathrm{~kg}$ de alimentos in natura foram doados para aqueles que a cidade não consegue alimentar. Também foram entregues 1.500 litros de leite ao Hospital das Clínicas da Universidade Federal do Paraná e, até primeiro de julho, 17.600 refeições já foram elaboradas para pessoas em situação de vulnerabilidade, como moradores de rua e de ocupações urbanas, em parceria do MST com outras entidades da cidade (como o Movimento Nacional da População de Rua e o Projeto Mãos Invisíveis). 
EM

QUESTÃO

V.13 N. $03 \bullet 2020$

pág. 179-201

Fotografia 13 - A produção de assentamentos e acampamentos do Paraná em lugar de partilha.

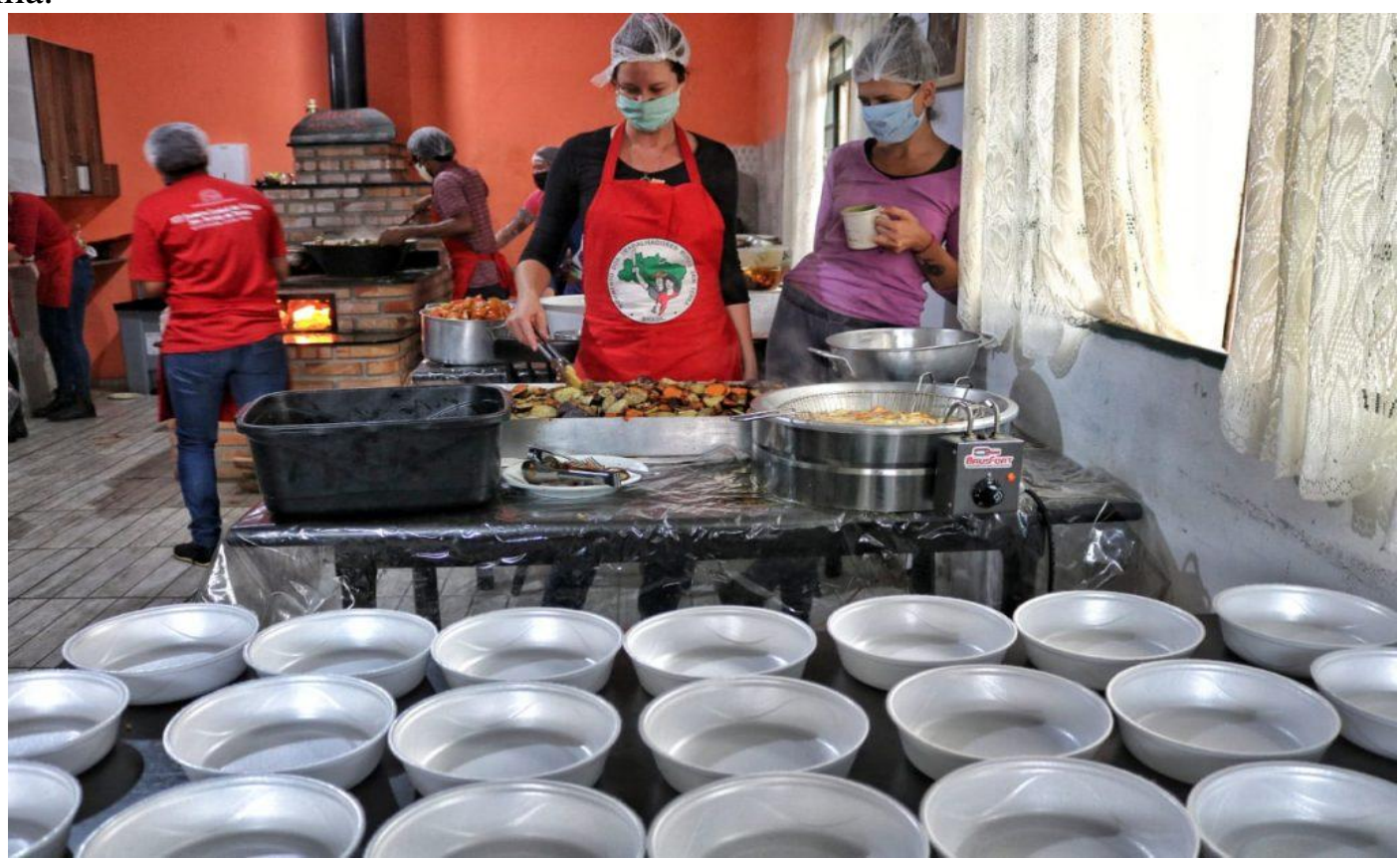

Foto: Giorgia Prates, 07/05/20.

A habitual falta de política pública e de respeito dos direitos fundamentais para esses grupos se agrava em épocas de crise sanitária, econômica e política... e a cidade nem roça, nem planta o suficiente para auto-abastecer-se, por enquanto.

Fotografia 14 - Cultivando a superação da crise na roça comunitária do acampamento Maria Rosa do Contestado, em Castro.

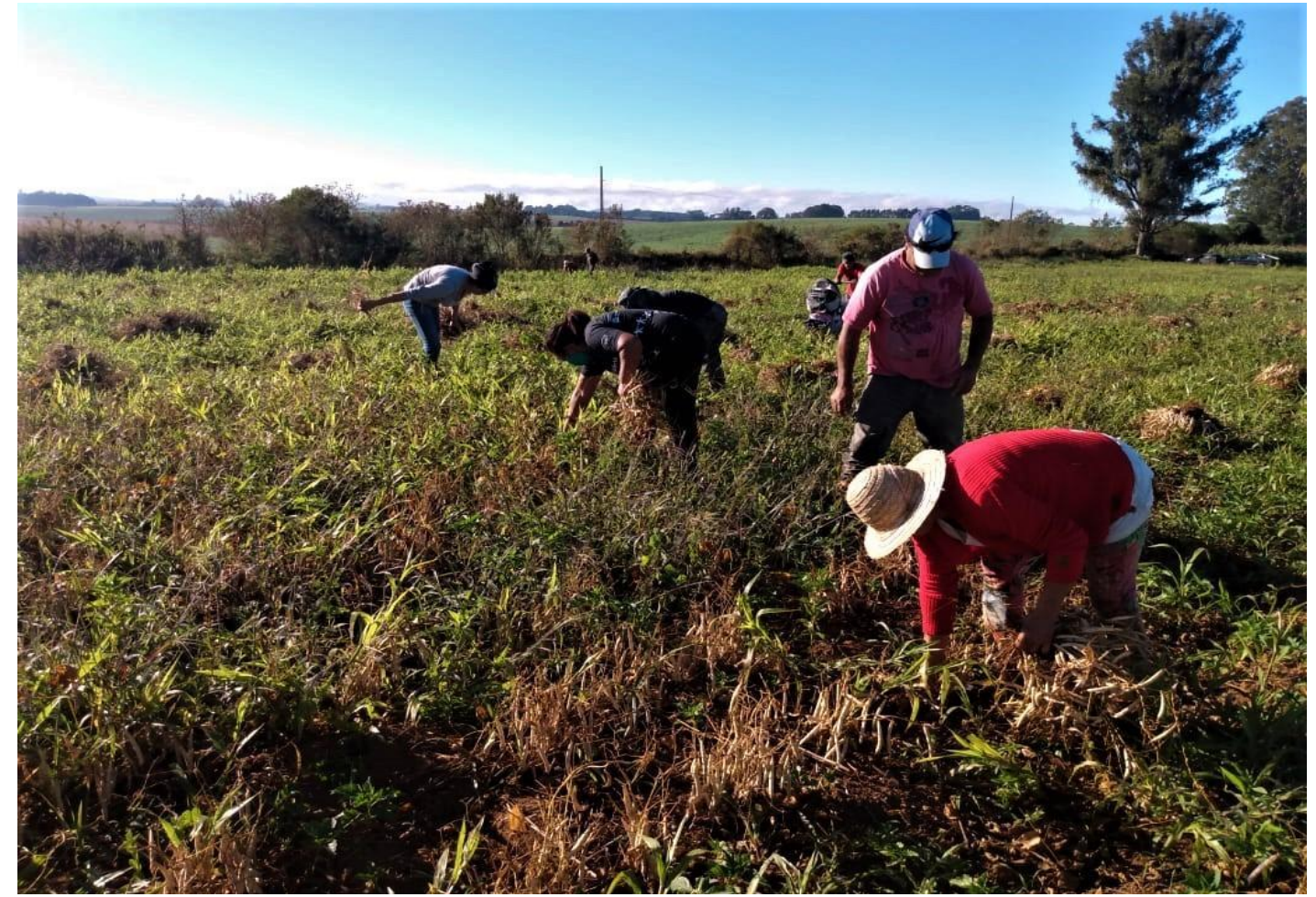

Foto: Rosane Mainardes. 
EM

Ocupações urbanas da Cidade Industrial de Curitiba (CIC), de outros bairros da capital e de cidades do entorno metropolitano (como Araucária, Campo Magro e Almirante Tamandaré) receberam alimentos nos dias 11 e 13/04, 13/05, 13/06, 22/07 e 01/08, no entanto, a solidariedade popular entre campo e cidade vem de longe. Quando em dezembro de 2018 um incêndio criminoso arrasou uma parte da ocupação 29 de Março (CIC), o MST também se somou a um grupo diverso de parceiros que ajudaram na reconstrução. Agora foram o arroz, feijão, mandioca, legumes, frutas, hortaliças e até 1.100 pães produzidos no acampamento Maila Sabrina, de Ortigueira, que viajaram $300 \mathrm{~km}$ para serem distribuídos entre famílias que já no início da pandemia não conseguiam garantir sua alimentação. De outros municípios do estado também chegaram alimentos: do assentamento Contestado e agricultores sócios da cooperativa Terra Livre da Lapa; dos assentamentos São Joaquim, Rio da Areia e Carvorite, de Teixeira Soares; do assentamento Dom José Gomes e Avencal, de Fernandes Pinheiro; do assentamento Mário Lago, de Irati; do acampamento José Lutzenberger, de Antonina; de produtores da agricultura familiar da Colônia Marcelino, de São José dos Pinhais; da Cooperativa da Reforma Agrária Coana, de Querência do Norte; e da cooperativa Copacon, do assentamento Eli Vive, de Londrina. Nesse encontro entre trabalhadores do campo e da cidade ressoam frases de gratidão e de satisfação. Agradecimento dos que recebem as doações e contentamento dos que podem ser úteis quando necessário.

Fotografia 15 - Das mãos dadas dos acampamentos e assentamentos de sete municípios do estado para as comunidades urbanas ocupadas de Curitiba, Araucária e Campo Magro.

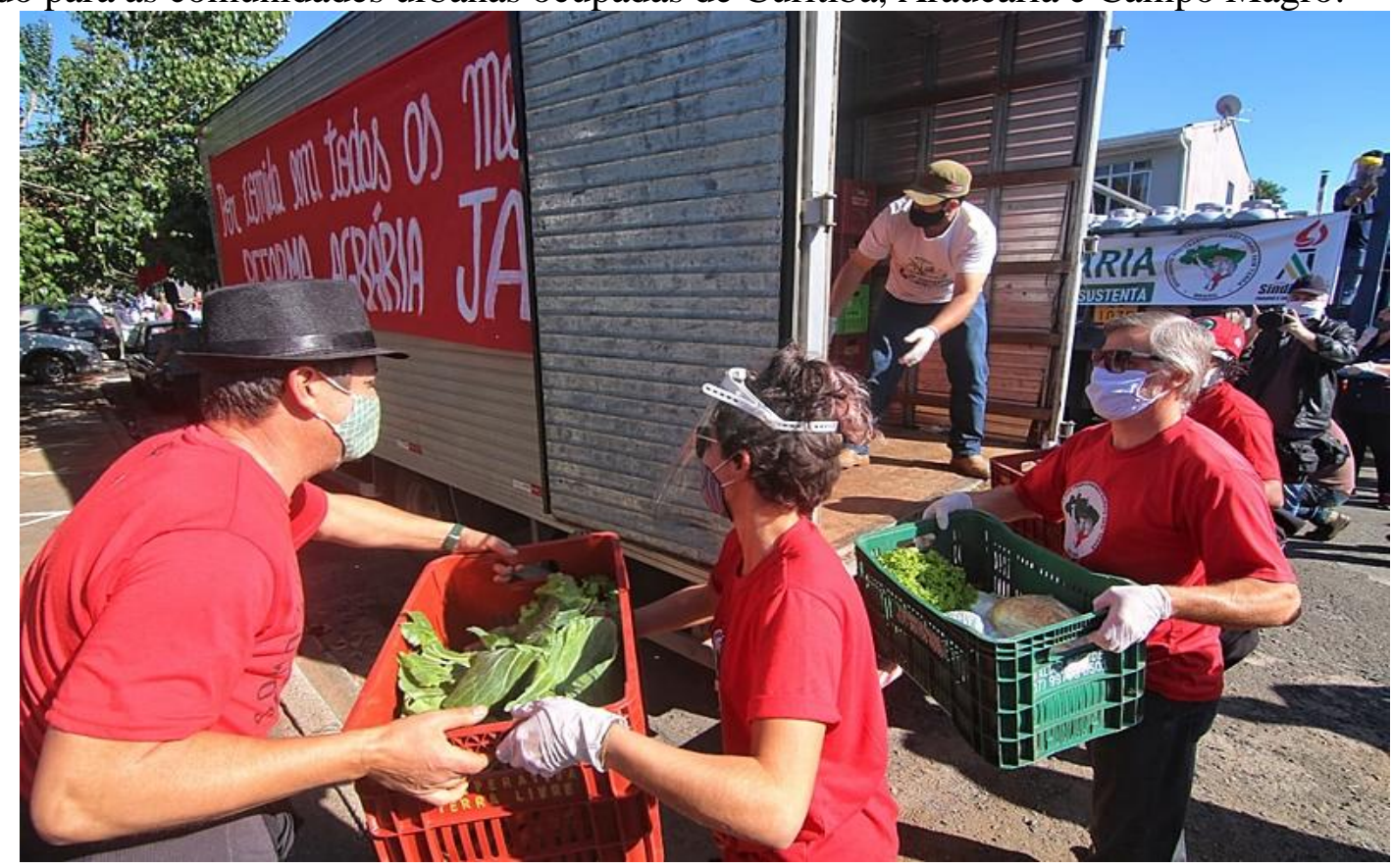

Foto: Giorgia Prates, 03/08/20.

Também em Curitiba e na vizinha Piraquara, os indígenas da aldeia Kakané Porã e da aldeia Araçaí, respectivamente, receberam alimentos distribuídos por coletivos de solidariedade que, junto ao MST, se fizeram presentes na semana em que se comemorava o Dia do Índio (19/04). Sem nada a festejar, com a COVID-19 afetando gravemente as aldeias de todo o país sob o descaso do Estado, a solidariedade em forma de alimento reforça os laços comuns entre indígenas e camponeses, ambos protagonistas do enfrentamento contra a expansão do agronegócio e ambos alvos preferenciais das políticas de criminalização e redução de direitos. 
EM

Ainda na Região Metropolitana de Curitiba, o assentamento Contestado levou 5.500 $\mathrm{kg}$ de alimento agroecológico aos mais necessitados no bairro São Lucas, na cidade da Lapa, no Dia Internacional da Luta Camponesa (17 de abril) e no dia 31/07.

Fotografia 16 - Ato político com agroecologia: do Assentamento Contestado à quem tem fome na Lapa.

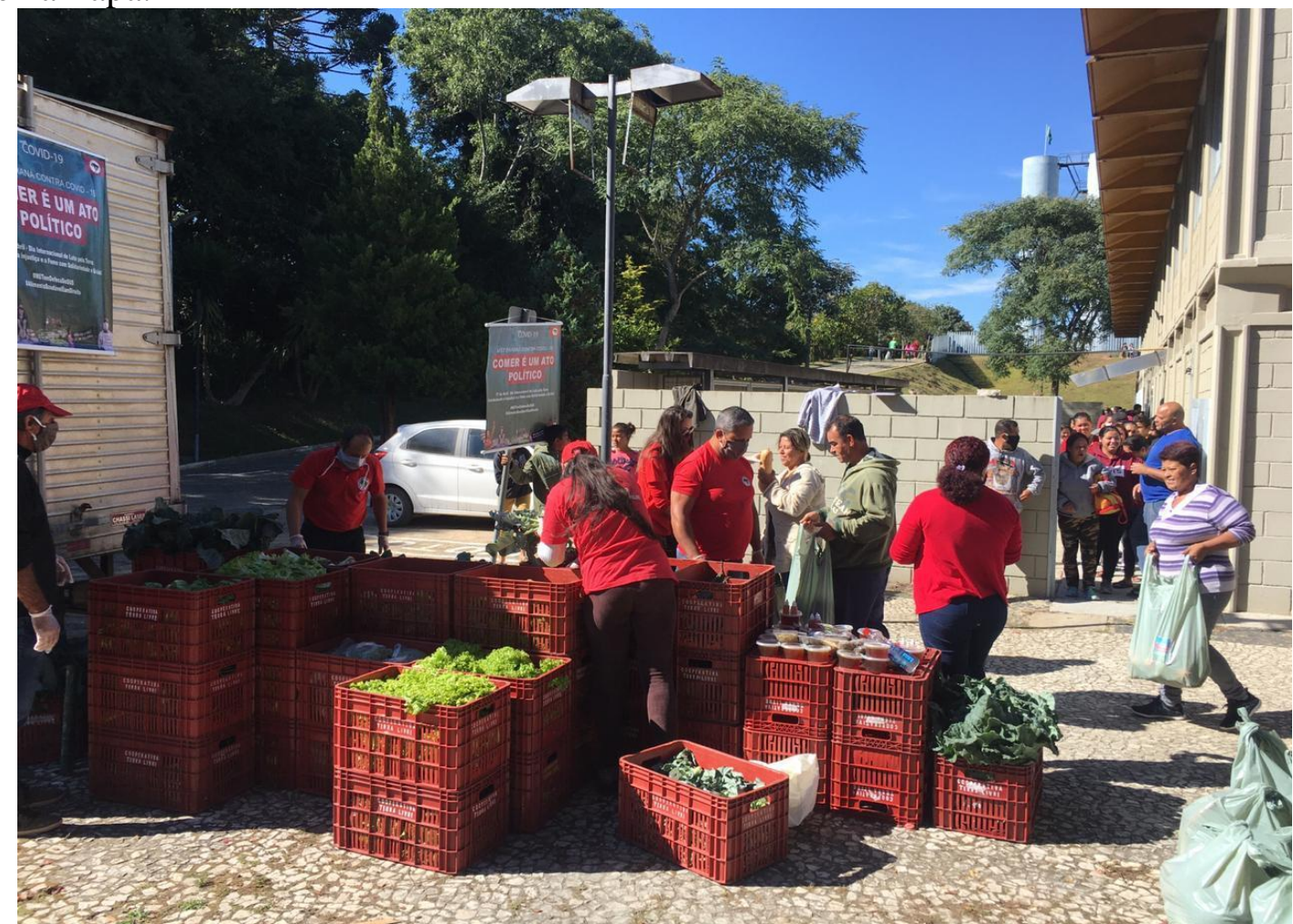

Foto: Wellington Lenon, 17/04/20.

$\mathrm{Na}$ região centro-oriental do estado, duas cidades foram alvo das doações das acampadas e acampados, mostrando que a luta pela terra, ainda no estágio inicial do acampamento, permite estruturar uma produção considerável de alimentos para os mercados locais. Em uma região como a dos Campos Gerais, potência nacional e internacional do agronegócio, três acampamentos juntaram $17.000 \mathrm{~kg}$ de alimentos agroecológicos para doar nos dias 07/04 e 08/08: em Ponta Grossa, no Banco de Alimentos do Serviço de Obras Sociais da prefeitura e, em Castro, para famílias carentes e para o Centro de Referência da Assistência Social (CRAS). Para essas ações se mobilizaram os assentamentos Três Pinheiros, Três Lagoas, Conceição, acampamento Padre Roque Zimmermann e os agricultores e as agricultoras familiares da comunidade Lagoa dos Ribas e da Associação União em Castro e o assentamento Che Guevara e o acampamento Emiliano Zapata, de Ponta Grossa, mostrando que alimento fresco e saudável para a população em situação de vulnerabilidade não vem dos vizinhos Bunge, Cargill, Batavo ou Castrolanda. Apesar de ser o município que mais leite produz do país, o CRAS de Castro viu aumentar seus atendimentos em $200 \%$ no mês de maio. Agronegócio não rima com redistribuição nem com solidariedade.

Nos domínios da agricultura capitalista, o combate à reforma agrária se vale de muitos ardis, prevalecendo a criminalização e a invisibilização dos feitos daqueles que forjam a vida nas precárias frações de terra de trabalho. No município de Castro não é diferente, mas esse ambiente hostil tem como contraponto a capacidade de superação dos Sem Terra, a exemplo do Acampamento Padre Roque Zimmermann que, em menos de dois anos, se tornou 
EM

QUESTÃO

V.13 N. $03 \bullet 2020$

pág. 179-201

referência da produção local de alimentos agroecológicos, participando das duas ações de solidariedade no município.

Fotografias 17 e 18 - Resistência pela produção e para a doação do Acampamento Padre Roque, em Castro.

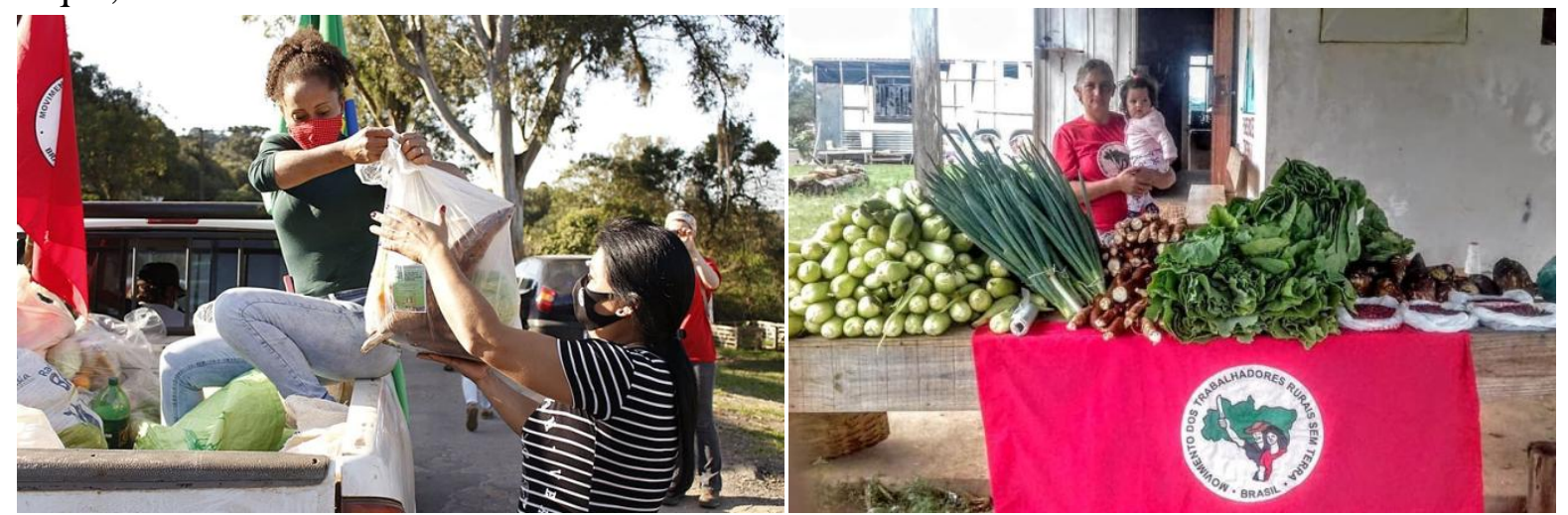

Foto: Luana Lustosa, 07/04/20.

Foto: Iara B. Falcade Pereira, 11/08/20.

A expressão resistência precisa ser compreendida no âmago de uma luta tão árdua quanto o é a luta pela terra no país do latifúndio, onde o descumprimento da função social da terra, ato constitucionalmente vedado e punível com a desapropriação para fins de reforma agrária, não cria constrangimentos legais e muito menos sociais. $\mathrm{O}$ acampamento Emiliano Zapata, de Ponta Grossa, chega à maioridade sem ter alcançado o assentamento definitivo. Implantado no dia 06 de outubro de 2002, responde à inércia do Estado produzindo alimentos agroecológicos no meio do agronegócio.

Fotografia 19 - Resistência feita de organização, produção e luta no acampamento Emiliano Zapata, de Ponta Grossa.

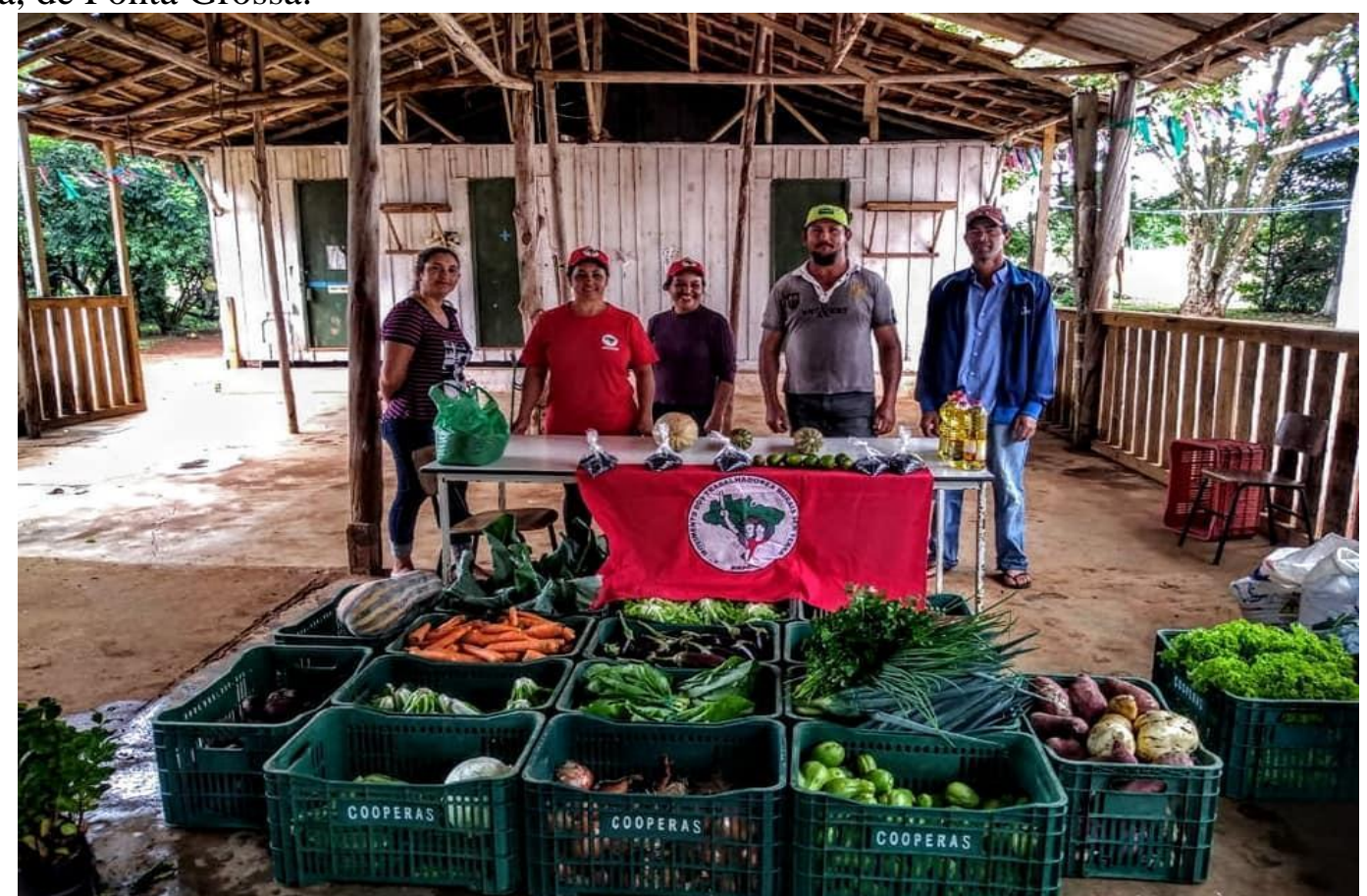

Foto: Larissa da Silva Santos, 07/04/20.

Como destacado, os acampamentos e assentamentos da mesorregião sudeste (municípios de Irati, Teixeira Soares e Fernandes Pinheiro) se mobilizaram para abastecer 
EM

QUESTÃO

V.13 N. $03 \bullet 2020$

pág. 179-201

Curitiba e cidades do entorno metropolitano no dia 01/08. E não foi sua única mobilização. No dia 15/08 junto com parceiros como sindicatos, cooperativas e comunidades de agricultores familiares, assentamentos de Bituruna como o 12 de Abril, Rondon III, Criciuminha, Santa Bárbara, 27 de Outubro, Etiene e Sonho de Rose e o acampamento Reduto Caraguatá, de Paula Freitas, se dirigiram para as cidades de São Mateus do Sul, Bituruna e General Carneiro com cestas carregadas de feijão, arroz, mandioca, batata doce, laranja, pães caseiros, hortaliças, temperos e outros alimentos para entregar a moradores dos bairros com maiores dificuldades para enfrentar a pandemia.

Fotografia 20 - Solidariedade a muitas mãos no Sudeste Paranaense.

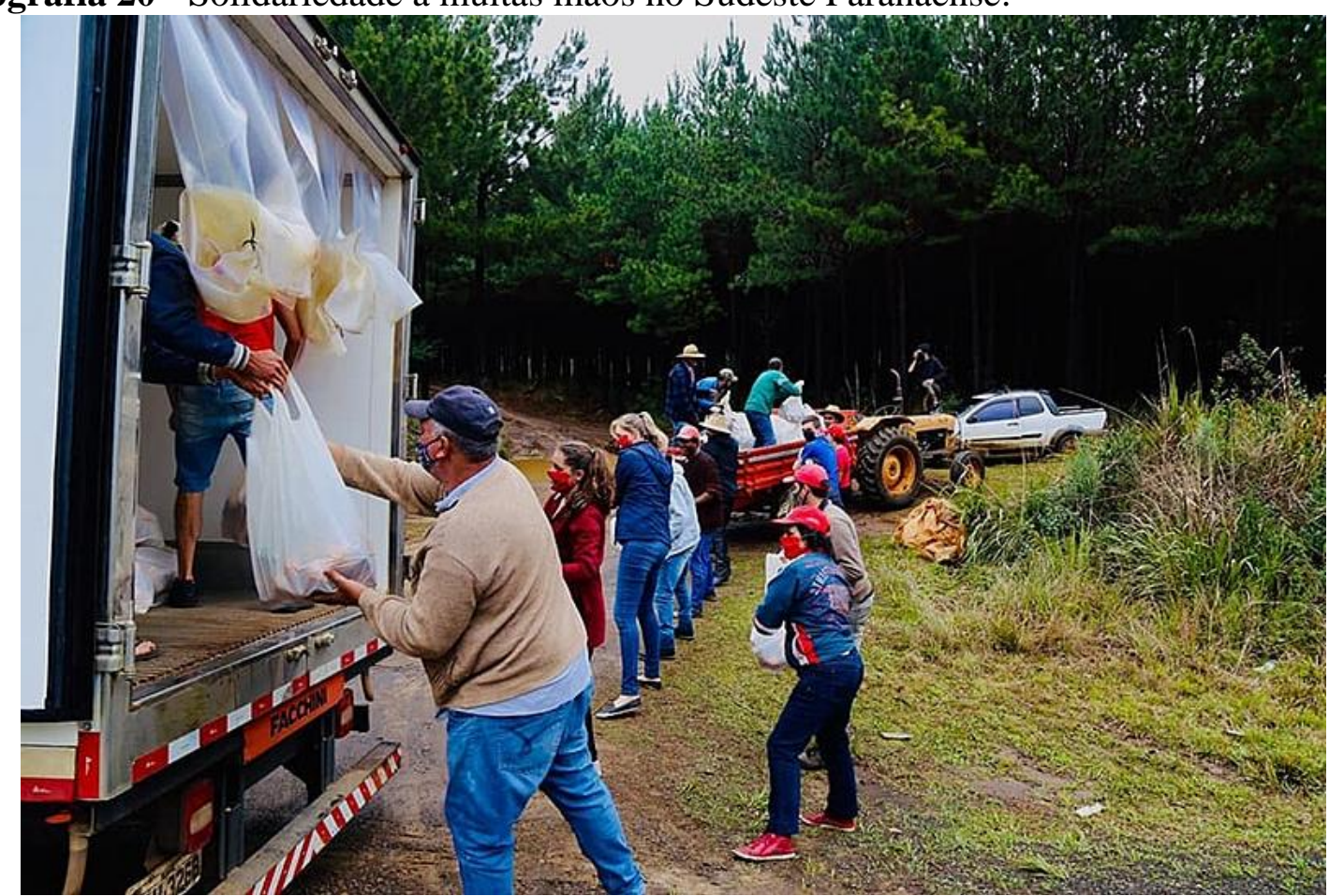

Foto: Wellington Lenon, 15/08/20.

Tal qual a pandemia, as ações de solidariedade em todo o estado e em todo país devem continuar, anunciando o que muita gente já sabe: a verdadeira solução aos grandes problemas não vem de cima para baixo, mas sim a partir da organização popular, nos campos e nas cidades, como aponta esse conjunto de iniciativas registradas no Paraná em cinco meses. A Assembleia Legislativa do estado (ALEP), por unanimidade, reconheceu esse trabalho com um Voto de Louvor no dia 14 abril. A mesma ALEP que, com contadas exceções, nada fez durante os despejos de nove acampamentos que deixaram mais de 500 famílias sem ter para onde ir e sem ter como e onde trabalhar para viver. Nas arenas da abastança, não há espaço que baste para a justiça triunfar.

\section{Limites à solidariedade: o acirramento da questão agrária no Brasil e no Paraná}

Apesar do completo desmonte da reforma agrária enquanto política pública capaz de combater a improdutividade e a impunidade dos que tomam o bem comum como coisa sua e fazem do dever constitucional de cumprimento da função social da terra motivo de escárnio, acrescida do esforço sem precedentes empregado em escala federal para enfraquecer seu legado, em sintonia com a maioria dos governos estaduais, a reforma agrária continua viva e 
EM QUESTÃO

fazendo sua parte pelo Brasil afora. Nos acampamentos e assentamentos, a organização política se alicerça na convicção inabalável nos direitos constitucionais e no cumprimento da função social da terra, ainda que a realidade fundiária do país se traduza em más notícias.

De fato, as assimetrias fundiárias seguem sendo brutais, a julgar pelos dados do último Censo Agropecuário (IBGE, 2017). Tomando-se a área média dos estabelecimentos brasileiros, verifica-se que mais de 2,6 milhões deles detém pouco mais de 3 hectares cada. Isso representa $52 \%$ das unidades agrícolas do país. Ou seja, mais da metade dos proprietários e proprietárias possuem uma terra que está muito longe de garantir os mínimos vitais, em sistemas convencionais de agricultura. $\mathrm{O}$ grau da concentração fundiária fica mais evidente se considerarmos que $83 \%$ dos estabelecimentos dividem entre si apenas 5\% do território nacional (pouco mais do equivalente ao Estado do Mato Grosso do Sul). Em números, são 4,2 milhões de estabelecimentos com 44.861 .698 hectares, o que significa área média de pouco mais de 10 hectares por estabelecimento, ainda unidades agrícolas de tamanho muito pequeno, exceto se foram dedicadas a cultivos agroecológicos ou com agroflorestas.

Menos exacerbada, mas igualmente escandalosa, é a situação no Paraná, onde $46 \%$ dos estabelecimentos têm dimensões médias inferiores a 3 hectares. Por sua vez, 3.220.614 hectares, o equivalente a $15 \%$ da superfície do estado, é o que sobra para $85 \%$ das unidades agrícolas, cuja área média é ligeiramente superior a 12 hectares. Os territórios da reforma agrária, 329 assentamentos onde vivem aproximadamente 20.360 famílias e 70 acampamentos com aproximadamente 7.000 famílias, são parte desse exíguo quinhão, extraordinariamente resiliente e capaz de responder aos desafios da diversidade e da qualidade na produção de alimentos.

Fotografia 21 - A fartura camponesa do Assentamento Contestado vai à mesa na Lapa.

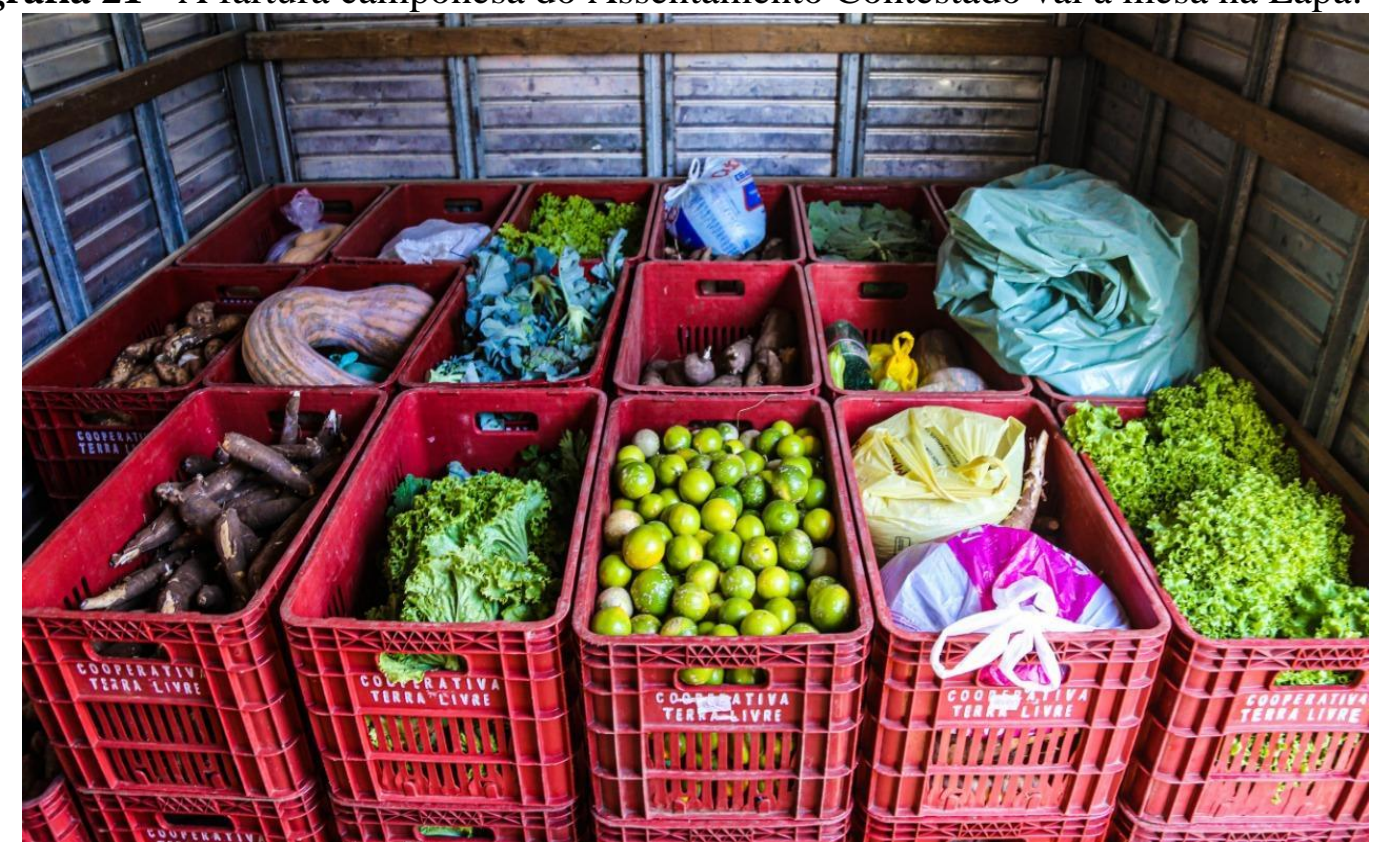

Foto: Wellington Lenon, 17/04/20.

Portanto, não é a debilidade dos camponeses, mas a força do latifúndio que explica essa injusta estrutura fundiária articulada aos problemas da expansão do capitalismo no campo. Nem durante os governos ditos progressistas se conseguiu mudar a distribuição nefasta. A defesa dos pretensos proprietários de enormes imóveis sempre foi matéria de Estado e a grilagem, as infrações trabalhistas ou dívidas milionárias com o fisco pouco penalizadas ou até permitidas. Nos últimos anos, a situação que parecia não poder ser pior, de 
EM QUESTÃO

fato se agravou. Exemplos recentes são as Leis 11.952/2009 e 13.465/2017, sobre regularização da grilagem nas terras da Amazônia Legal, bem como o Projeto de Lei 2633/2020, que amplia essa regularização para o restante do país: todos eles absolvem esse ato definido como crime desde $1850^{9}$ e premiam os invasores endinheirados com o direito de propriedade sobre as terras extraídas do patrimônio público pela força da fraude. A grilagem está sendo apagada da história do país ${ }^{10}$.

Sinais da dimensão desse problema estão nos dados compilados do Cadastro de Imóveis (INCRA, 2014), segundo os quais havia 2.175 municípios (quase 4 de cada 10 municípios) em 2014 cuja área declarada como de propriedade dos imóveis era maior do que a própria extensão territorial dos mesmos. Naquela ocasião, 132.546.552,8 hectares, ou 16\% do território nacional, estavam sob esta modalidade de fraude documental, sabendo-se que isso é a ponta do iceberg, pois a falsificação de títulos é um expediente de larga utilização desde a instauração do regime de propriedade privada no país.

Fotografia 22 - Produção agroecológica do acampamento Maria Rosa do Contestado, de Castro.

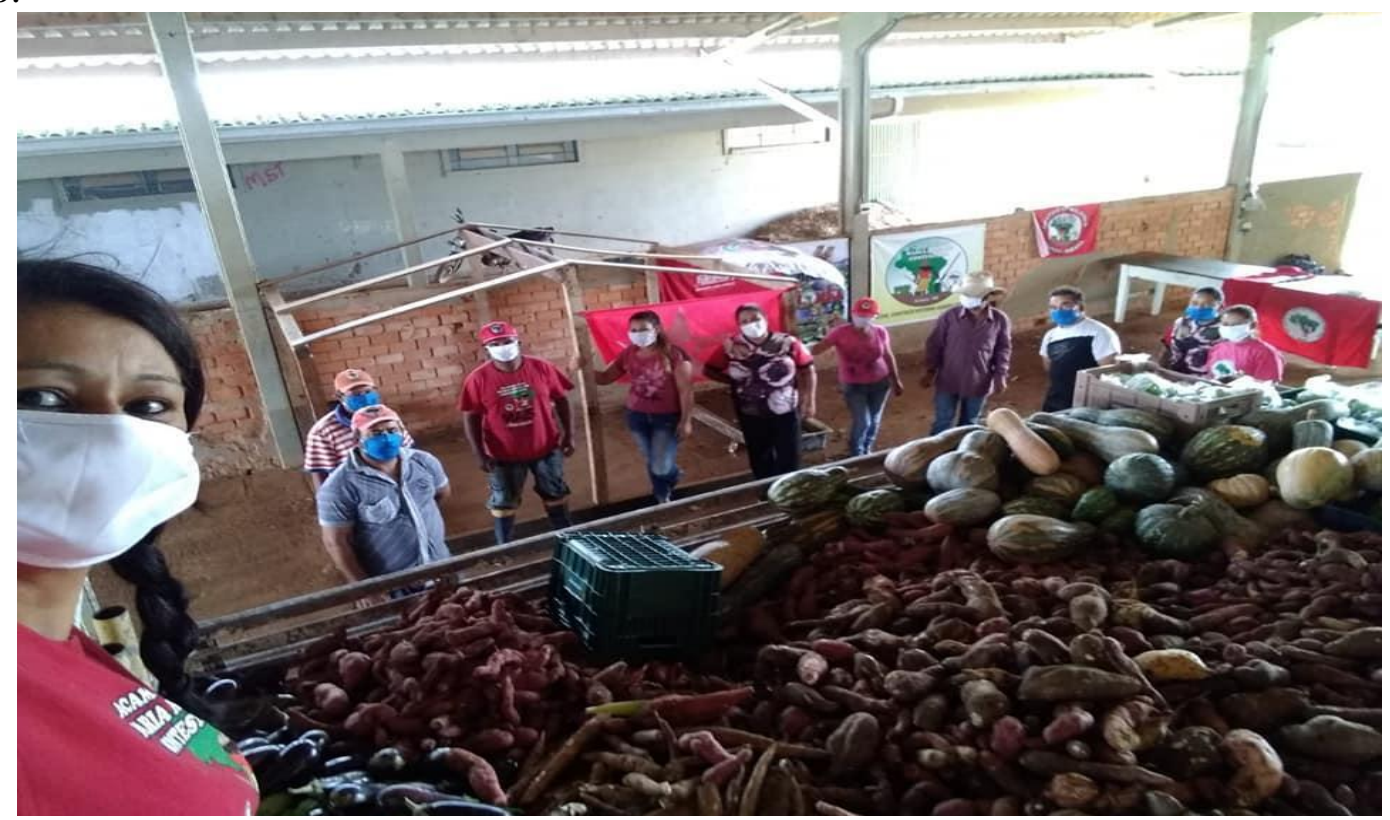

Foto: Rosane Mainardes, 07/04/20.

No Paraná, 214 municípios compareciam nos registros oficiais com área dos imóveis maior que a extensão verdadeira, havendo 2.707 .085 hectares ou 14\% do território estadual sob fraude documental. Dentre os que se apresentam como donos de imóveis no Paraná, 87.052 assumiram diante do INCRA não possuir registro de propriedade. Somados, chegamos à extensão de 2.721 .875 hectares. Dentre eles, 176 estão em posse de 641.188 hectares, o equivalente à área média de 3.643 hectares cada (FONSECA, 2019, p. 86). O latifúndio e o agronegócio respondem pela grilagem também no Paraná ${ }^{11}$.

\footnotetext{
${ }^{9}$ No artigo $2^{\circ}$ da Lei de Terras de 1850 a grilagem se pune assim: "Os que se apossarem de terras devolutas ou de alheias, e nellas derribarem mattos ou lhes puzerem fogo, serão obrigados a despejo, com perda de bemfeitorias, e de mais soffrerão a pena de dous a seis mezes do prisão e multa de 100 \$, além da satisfação do damno causado".

${ }^{10}$ Inclusive mantendo a fraude e a imoralidade que acompanharam as grandes apropriações de terra no país, como denuncia a página de jornalismo investigativo "De olho nos ruralistas" nas matérias "Aliado de relator da MP da Grilagem abriu empresa para regularizar terras em Minas" (11/05/2020) e "Texto de Irajá na MP da Grilagem beneficia negócios do padrasto" $(11 / 05 / 2020)$.

${ }^{11}$ Entendemos que a questão agrária não se resume à concentração fundiária, ainda que seja um elemento essencial, em todo caso, para uma visão panorâmica da questão agrária paranaense considerando elementos como conflitos por terra e território, presença indígena e de comunidades tradicionais, gênero no campo, agroecologia, conflitos socioambientais, agrotóxicos e
} 
EM

Para concluir....mas não des(esperar)

A doação de alimentos proveniente de acampamentos e assentamentos pode renovar a força da memória dos despojados que sobreviveram para contar como, onde e quem se apropriou ilegalmente de terra. É preciso despertar a memória de toda a sociedade sobre tais atos ilegais, imorais e que engordam tão somente o patrimônio daqueles que pouco tem a oferecer em termos de cumprimento da função social da terra.

Os camponeses do MST continuam buscando uma sociedade mais justa, solidária e livre, onde a centralidade seja a vida, uma vida que mereça a pena ser vivida. Estímulos dessa natureza soam como antídoto ao desânimo ou ao imobilismo tão característico desse tempo crítico.

A boa notícia é que pessoas concretamente comprometidas com uma sociedade melhor a tornam melhor: as ações aqui relatadas são um entre muitos exemplos. Embora estejamos expostos a mensagens de ódio, desalento e medo, notícias de um outro mundo que já está sendo construído abrem brechas no muro. Queremos finalizar este trabalho com apenas três delas, por onde podemos entrever o protagonismo do campesinato nessa direção.

A primeira é a Campanha para o fortalecimento do PAA para lutar contra os efeitos da pandemia $^{12}$. Mais de 300 movimentos e organizações sociais do campo e da cidade estão lutando por reativar o Programa de Aquisição de Alimentos da Agricultura Familiar (PAA). Contra uma política de financiamento focada no agronegócio (o último Plano Safra destina apenas $14 \%$ para a agricultura familiar) demanda-se a aplicação de $\mathrm{R} \$ 1$ bilhão durante 2020 e de $\mathrm{R} \$ 3$ bilhões em 2021 para fazer frente à crise provocada pela pandemia.

Essa medida serviria para levar alimento à mesa das brasileiras e brasileiros sem meios para comprar comida e garantiria a renda das camponesas e camponeses que insistem na seara de produzir comida e não commodity. No Plano Safra 2020/2021, foi destinado ao PAA exíguos R\$ 220 milhões, quase quatro vezes menos do que fora liberado ao programa em 2012 e perto de um quinto do bilhão reivindicado. Razões para a luta continuar porque a demanda de alimentos da população mais castigada pela pandemia, segue em aumento sem que o Estado esteja logrando êxito em supri-la ${ }^{13}$.

A segunda seria o Plano Emergencial de Reforma Agrária Popular ${ }^{14}$. Lançado no dia 05 de junho último, o plano se estrutura em quatro eixos: assentamento das famílias em acampamentos no meio rural e nas ocupações urbanas fazendo cumprir a constituição; produção de alimentos saudáveis mediante ampliação do PAA, implantação do Plano Nacional de Agroecologia e organização de hortas urbanas agroecológicas; proteção da natureza, água e biodiversidade, banindo os agrotóxicos, promovendo a produção de sementes agroecológicas e as agroflorestas; melhora das condições de vida no campo, mantendo as escolas do campo e programas como o PRONERA, com financiamentos para moradia, para melhora da saúde e para programas de combate à violência doméstica.

\footnotetext{
educação do campo consultar o "Atlas da Questão Agrária no Paraná: diálogos em construção" (OBSERVATÓRIO DA QUESTÃO AGRÁRIA NO PARANÁ, 2020).

${ }_{12}$ Para mais informações, consultar: https://agroecologia.org.br/wp-content/uploads/2020/04/PAA-Comida-Saudavel-para-OPovo.pdf

${ }^{13}$ Mesmo quando as notícias são francamente retrógradas, a resistência não cessa. As medidas que o governo Bolsonaro está tomando em relação aos que produzem comida, como o veto praticamente integral ao Projeto de Lei de apoio financeiro dos agricultores familiares durante a pandemia de Covid-19 (PL 735/2020). Contrariamente, vem fortalecendo o empresariado rural com benesses fiscais e creditícias e, sobretudo, com a desregulamentação que almeja o retorno do direito absoluto de propriedade, coisa da qual o Brasil se livrou, na letra da lei, há quase dois séculos. Ver a carta de denúncia "Pela Garantia de Alimentos Saudáveis e Sustentáveis contra a Fome e a Política Genocida do Governo Bolsonaro" (PELA GARANTIA, 2020).

${ }^{14}$ Uma boa síntese do Plano pode ser encontrada em: https://www.brasildefato.com.br/2020/06/15/ponto-a-ponto-conheca-oplano-de-reforma-agraria-popular-defendido-pelo-mst.
} 
EM QUESTÃO V.13 N. $03 \bullet 2020$ pág. 179-201

Fotografia 23 - Rede de solidariedade rural-urbana se fortalece na doação de alimentos em Cascavel.

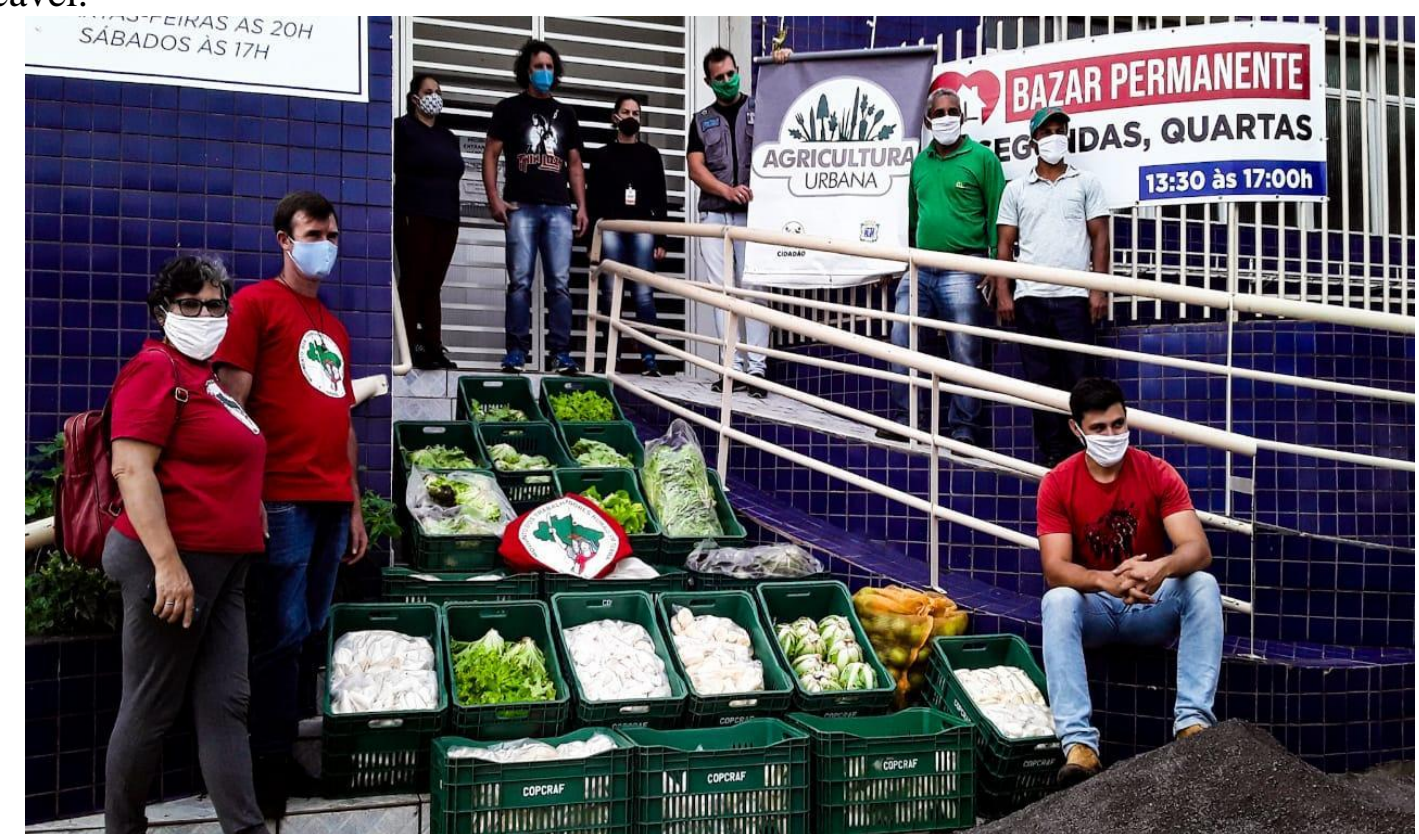

Foto: Eliana de Oliveira, 17/04/20.

Por fim, as hortas comunitárias em acampamentos do Paraná. Em homenagem a Antônio Tavares, assassinado em maio de 2000 pela Polícia Militar do Paraná durante mobilização pela reforma agrária na BR 277, foram criadas hortas e agroflorestas comunitárias em acampamentos situados nos seguintes municípios: Castro, Cascavel, Boa Ventura de São Roque, Pinhão, Clevelândia, Guarapuava, Quinta do Sol, Centenário do Sul, Planaltina do Paraná, Catanduvas, Ortigueira, Florestópolis e Porecatu. Produção coletiva de alimentos frente à violência do Estado é um bom resumo do que está acontecendo durante esta pandemia.

Se o agronegócio segue produzindo grãos e carnes para vender somente para quem pode comprar e à custa da saúde dos seus empregados ${ }^{15}$ e de todos os que não tem como escapar da cultura do veneno, a força da reforma agrária está no contraponto alentador de produzir e compartilhar alimentos, sendo capaz de manter a solidariedade em momentos difíceis e de construir propostas para transformar a sociedade em colaboração com a maioria. O desafio é imenso, mas os camponeses do MST nos dão razões de sobra para seguirmos caminhando e cantando e seguindo a canção.

\section{Referências}

CASTILHO, Alceu Luís; FUHRMANN, Leonardo. Aliado de relator da MP da Grilagem abriu empresa para regularizar terras em Minas. Disponível em: https://deolhonosruralistas.com.br/2020/05/11/aliado-de-relator-da-mp-da-grilagem-abriuempresa-para-regularizar-terras-em-minas/. Acesso em: 25 sep. 2020.

ENCONTRADA relação entre casos da Covid-19 e trabalho em frigoríficos. Instituto Federal de São Paulo, São Paulo, 29 de maio de 2020. Disponível em:

\footnotetext{
${ }^{15}$ Para verificar a relação entre COVID-19 e trabalho nos frigoríficos consultar o trabalho dos professores Heck e Nascimento Júnior (ENCONTRADA, 2020). Para uma análise global da forma em que o agronegócio tem uma responsabilidade fundamental nos surtos epidêmicos como a Covid-19 ver Wallace (2020).
} 
EM

QUESTÃO

V.13 N. $03 \bullet 2020$

pág. 179-201

https://www.ifsp.edu.br/component/content/article/17-ultimas-noticias/1488-pesquisadoresdo-ifsp-e-ufsc-encontram-relacao-entre-casos-da-covid-19-e-as-condicoes-de-trabalho-nosetor-de-frigorificos. Acesso em: 25 set. 2020.

FIOCRUZ. Monitora Covid-19. Disponível em: https://bigdata-covid19.icict.fiocruz.br/. Acesso em: 24 set. 2020.

FONSECA, Silas Rafael da. Latifúndio (im)produtivo e impasses à recriação camponesa no sudeste paranaense. 2019. 375 f. Tese (Doutorado em Geografia) - Universidade Estadual de Londrina, Londrina, 2019.

FUHRMANN, Leonardo. Texto de Irajá na MP da Grilagem beneficia negócios do padrasto. deolho nos ruralistas, São Paulo, 15 maio 2020. Disponível em: https://deolhonosruralistas.com.br/2020/05/11/texto-de-iraja-na-mp-da-grilagem-beneficianegocios-do-padastro/. Acesso em: 25 sep. 2020.

HADICH, Ceres. Muito prazer, somos o MST. Brasil de Fato, Coluna Paraná, 20 maio 2020. Disponível em: https://www.brasildefatopr.com.br/colunistas/ceres-hadich. Acesso em: 23 jun. 2020.

IBGE. Censo Agropecuário 2017. Banco de Dados Agregados. Disponível em: http://sidra.ibge.gov.br.

INCRA. Incra nos Estados: informações gerais sobre os assentamentos da Reforma Agrária. Disponível em: http://painel.incra.gov.br/sistemas/index.php. Acesso em: 25 jun. 2020.

- Sistema Nacional de Cadastro Rural: estatísticas cadastrais situação jurídica em 2014. Banco de Dados - não publicado.

OBSERVATÓRIO DA QUESTÃo AGRÁRIA NO PARANÁ. Atlas da Questão Agrária no Paraná: diálogos em construção. Naviraí-MS: Territórios e R-existências, 2020 (no prelo).

PELA GARANTIA de Alimentos Saudáveis e Sustentáveis contra a Fome e a Política Genocida do Governo Bolsonaro. CPT Nacional, Goiás. Disponível em: https://cptnacional.org.br/publicacoes/noticias/geral/5382-pela-garantia-de-alimentossaudaveis-e-sustentaveis-contra-a-fome-e-a-politica-genocida-do-governo-bolsonaro. Acesso em: 25 set. 2020.

WALLACE, Rob. Pandemia e agronegócio. Doenças infecciosas, capitalismo e ciência. São Paulo: Elefante, 2020. 